\title{
مستوى أداء معلمي اللغة العربية في المرحلة الابتدائية في مهارات تدريس المحادثة
}

د. محمد هادي حسن الشمري

جامعة واسط - كلية التربية

" ملخص البحث "

يرمي هذا البحث إلى معرفة " مستوى إداء معلمي اللغة العربية في المرحلة الابتدائية في مهارات تدريس المحادثة

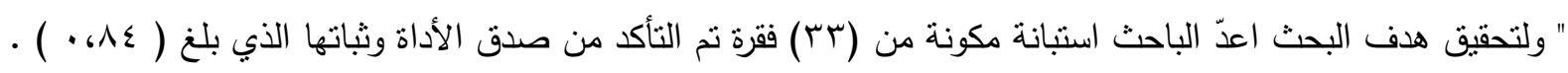

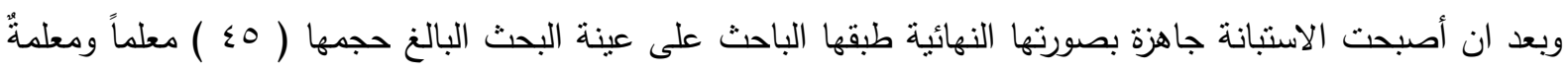

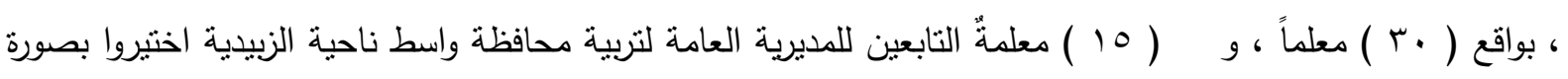

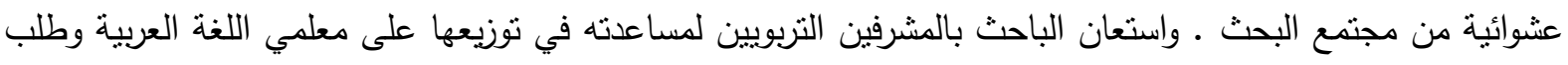

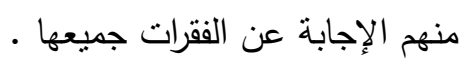

وباستعمال الوسائل الإحصائية المناسبة الوسط المرجح والوزن المئوي والاختبار التائي تبين للباحث أن هناك قلة

اهتمام بالمهارات التعليمية لتدريس المحادثة عند المعلمين • ولا نوجد فروق ذات دلالة إحصائية بين المتوسط الحسابي

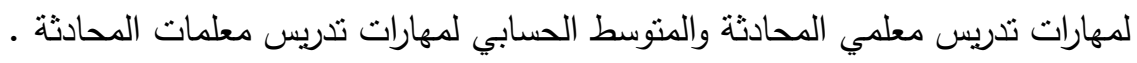
وقد أوصى الباحث بضرورة تدريب المعلمين على استعمال المهارات التعليمية في تدريس المحادثة لما لها من دور في في لثاني تحقيق أهداف تدريس المادة ، وتدريب المعلمين في أثناء الخدمة على طرائق التدريس الحديثة واطلاعهم على احدث المستجدات في مجال أساليب التدريس ، وتضمين مناهج ومقررات الأعداد المهني للطلبة في المعاهد والكليات الأساسية بالأساليب المهارات 


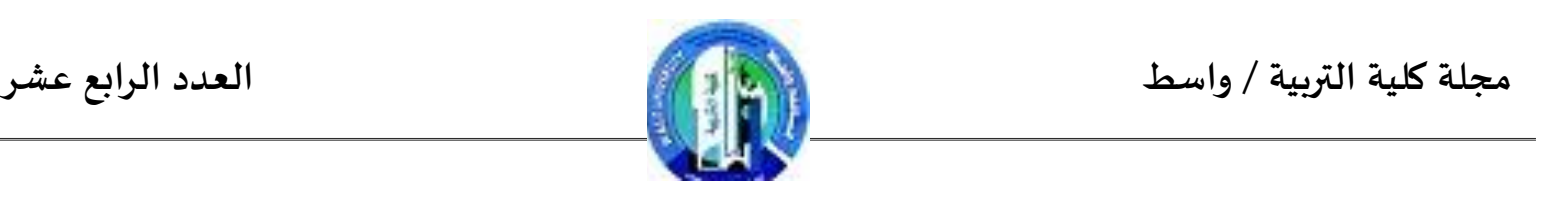

\title{
Performance level of Arabic language teachers for primary classes in conversation's teaching skills
}

\author{
Dr. Mohammed H. Hassan \\ University Of Wassit - College Of Education
}

\begin{abstract}
This research aims to know the "Performance level of Arabic language teachers for primary classes in conversation's teaching skills", for achieving this aim, the researcher prepared a note form which it formed of (33) paragraph where it had been assured of its performance truth and constancy at (0.84). After the completion of the survey in its final form, the researcher applied it on the research sample of (45) teachers ((30) males and (15) females) belong to the general directorate of education of Wassit provincel Az Zubeidiya city, they had been chosen in a random way of the research community. The researcher has been helped by educational supervisors in distributing the note forms on the Arabic language teachers where they must answer all the paragraphs.

By using the suitable statistical means (weighted average, weighted percentage and Ttest), it has been clarified that there is a little interest in teaching skills for conversation teaching at the teachers. And there is no difference between the arithmetical average of teaching skills for the male teachers and the arithmetical average of teaching skills for the female teachers.

The researcher recommended about the training necessity of teachers for on using the teaching skills in conversation teaching because of its lead in achieving the aims of teaching conversation subject. He recommended also on the training of teachers during the service on modern teaching methodologies and their knowledge of the last new in the scope of teaching methodologies. He recommended to implicate the curriculums and the officials of vocational preparatory for students in institutes and basic colleges with the methodologies of required suitable teaching skills.
\end{abstract}




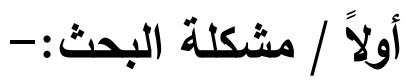

تعد اللغة العربية أداة للتوجيه الديني والتهذيب الروحي في الأمتين الإسلامية والعربية ، والوسيلة

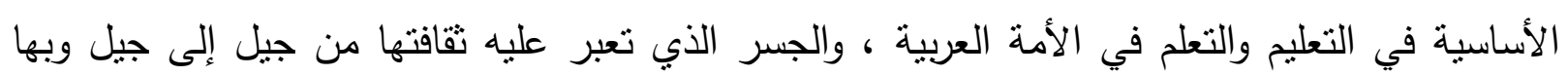

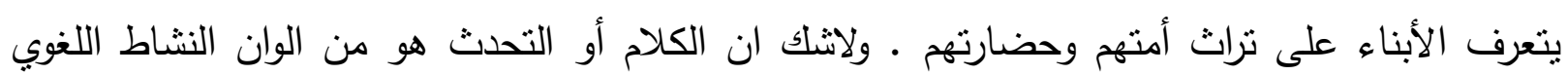

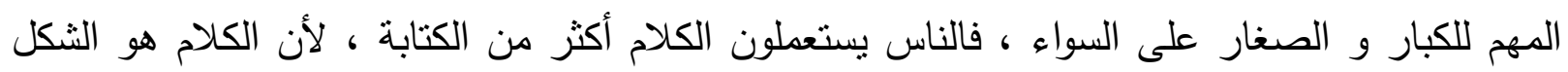

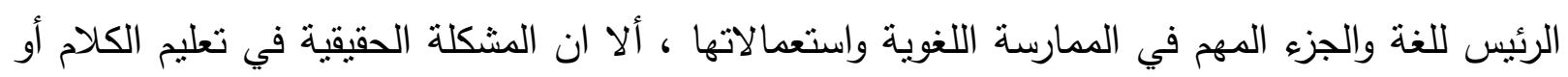

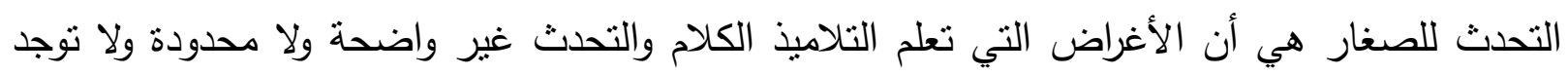

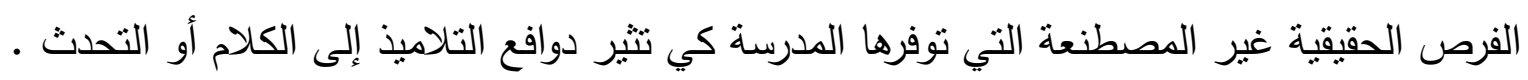

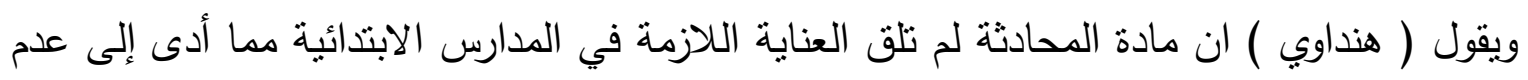

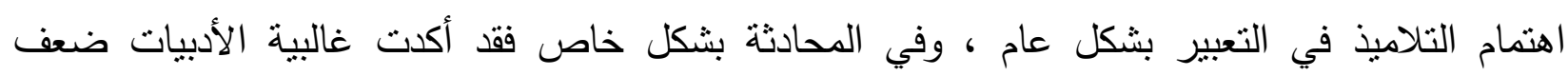

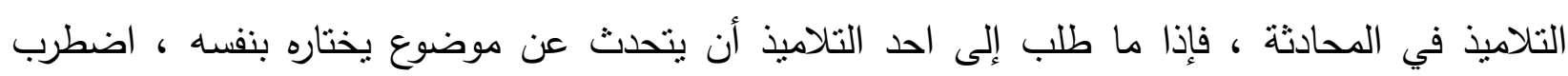

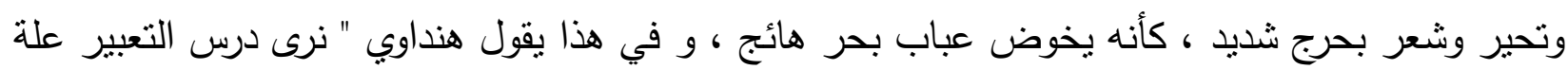

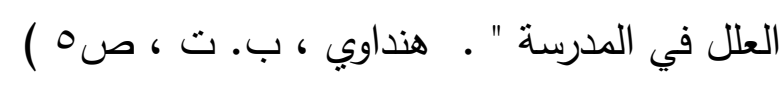

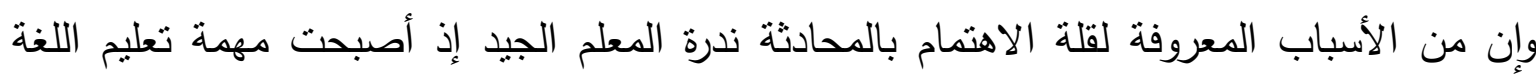

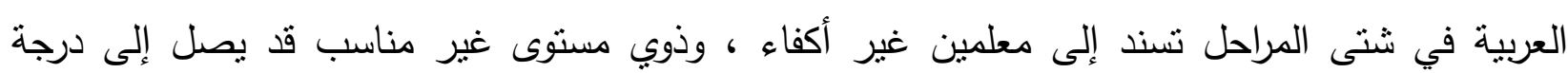

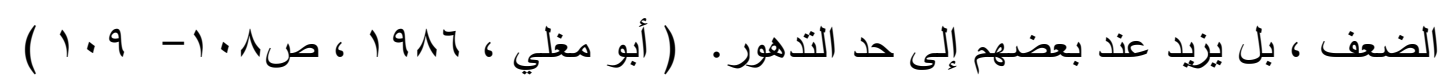

ومن خلال ما ذكر حول قلة الاهتمام بمادة المحادثة عند معلمي المرحلة الابتدائية دفع الباحث إلى ان

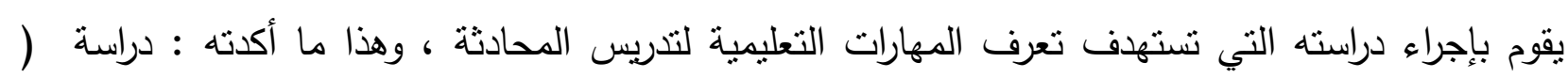

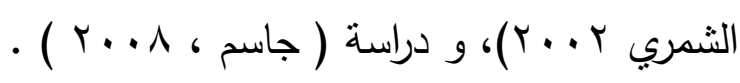




\section{ومما تقدم تكمن مشكلة البحث هذا في الأتي :-}

1- قلة اهتمام المرحلة الابتدائية في درس المحادثة لفئة على ما شخصته الدراسات السابقة .

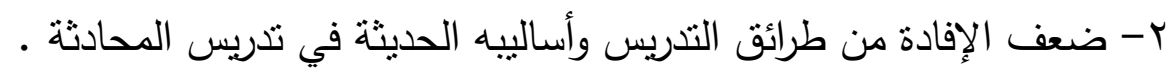
r- ضعف تحديد المهارات التعليمية واستعمالها في تدريس المحادثة .

\section{ثانياً / أهمية البحث والحاجة اليه :-}

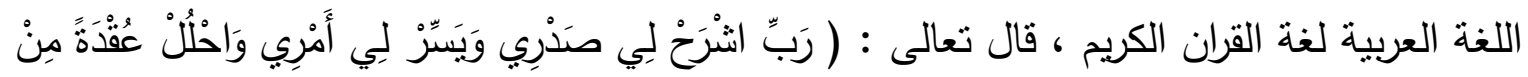

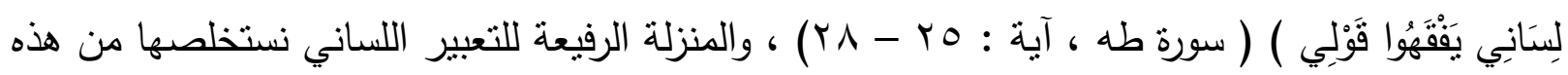
الآية الكريمة التي جاءت على لسان موسى (عليه السلام ).

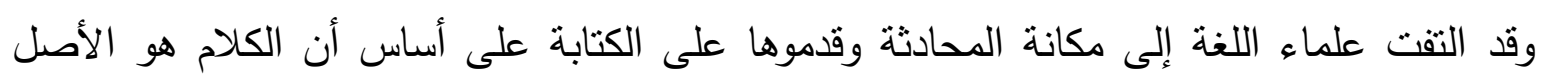

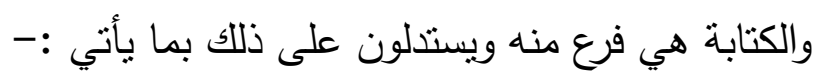

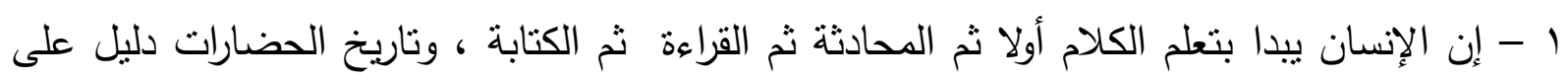
ذللك ، فاللغة وجدت أولا على الألسن ، ثم ظهرت الحاجة إلى تدوينها بعد توسع الأعمال ونشوء العلاقات التجارية . r - وان هناك الملايين من البشر لا يعرفون القراءة والكتابة ، وعدداً من اللغات لم تعرف الكتابة ولكننا

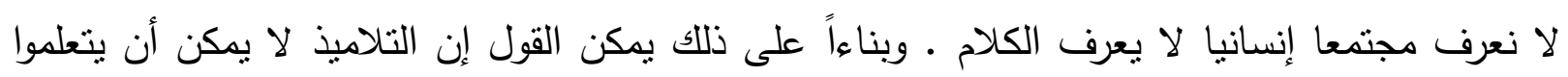

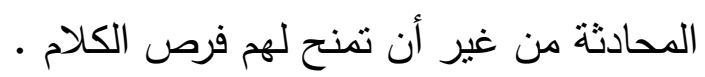


وتبرز أهمية المحادثة في رفع مستوى تعبير التلاميذ ، وإكسابهم المرونة في الحديث ، إذ إن إتقان المحادثة يساعد على تخطي كثير من صعوبات الازدواجية اللغوية التي يعاني منها أطفالنا وشبابنا

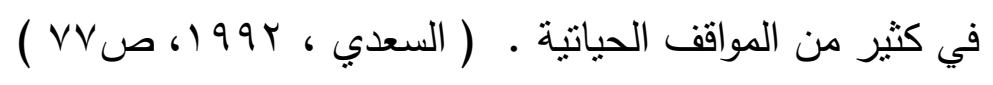

وإن اصطلاح لغة التلاميذ في مراحل التعليم الابتدائي يكون أمرا ميسورا إذا كان هناك التان اهتمام

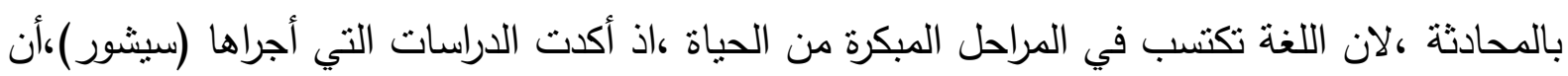

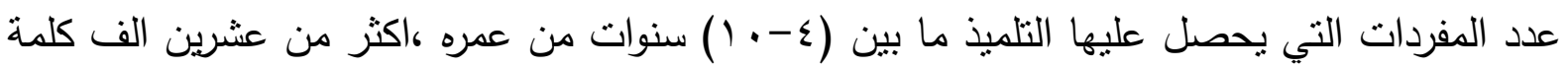

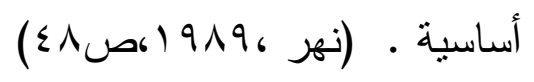

وجد الباحث ان تقويم المهارات التعليمية اللازمة لمعلمي اللغة العربية في تدريس المحادثة يسهر

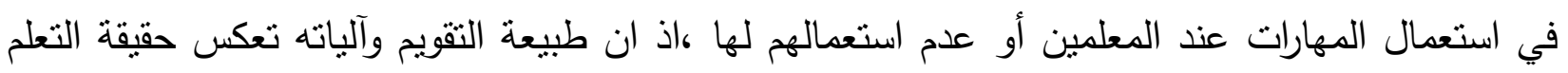

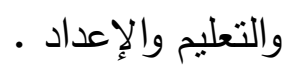

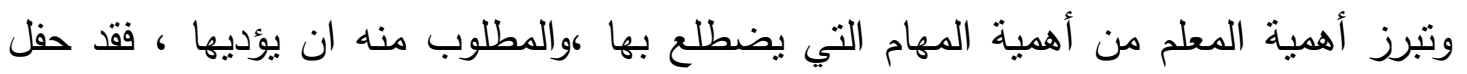

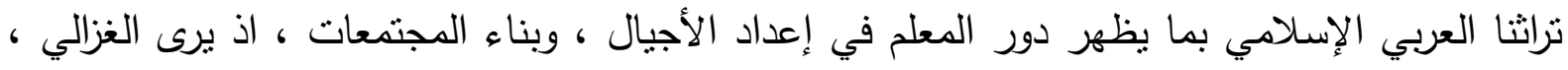

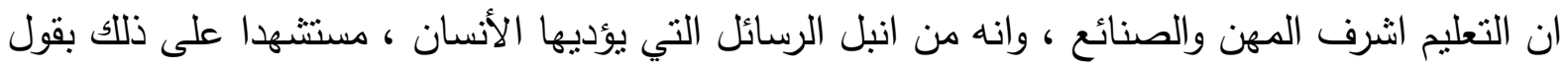

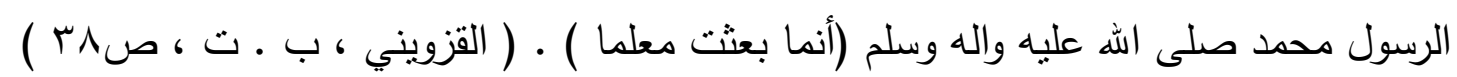

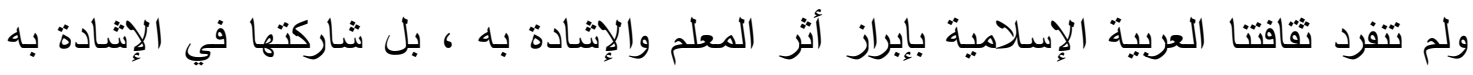

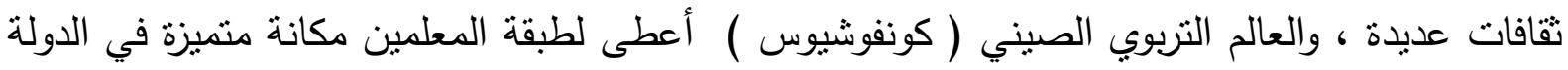

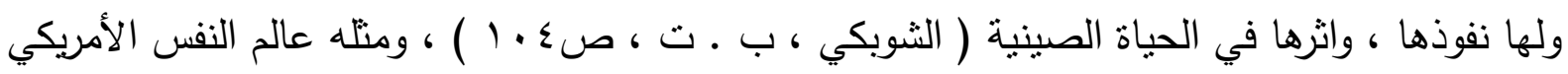

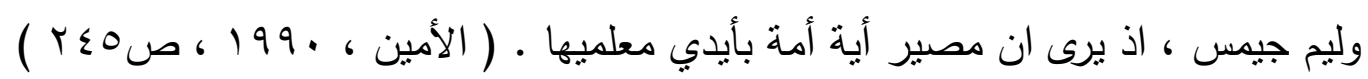

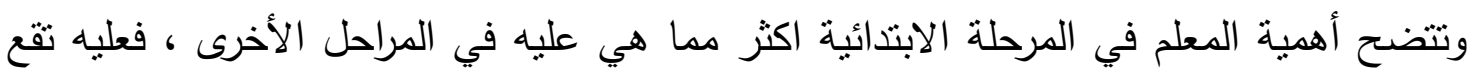

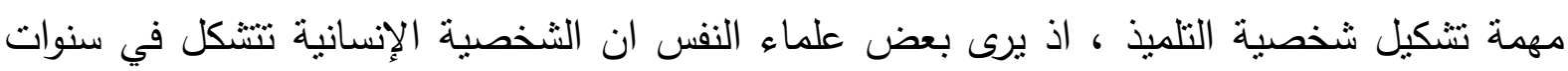

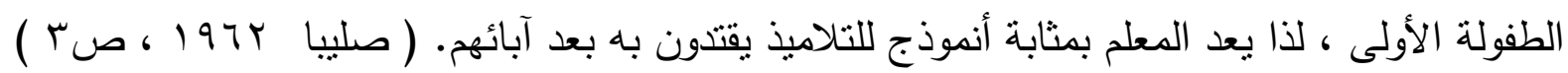

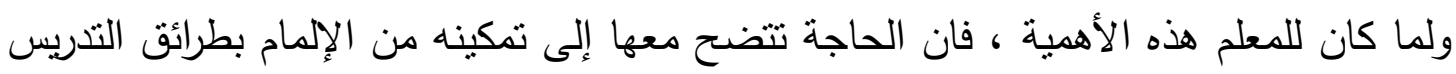

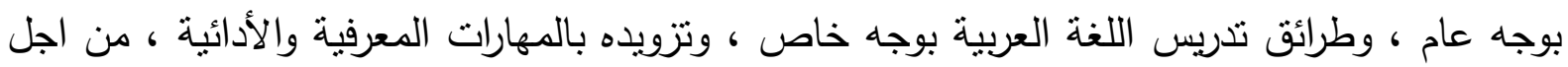


تحقيق الأهداف التي تطمح إليها الدولة ، لذا لم يعد مقدار ما يمتلكه المعلم من معلومات معيار للحكم

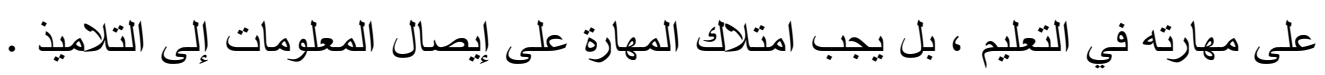
فقد اظهرت دراسات عديدة تؤكد ان المعلم المعد بموجب البرنامج القائم على الكفايات يتفوق في

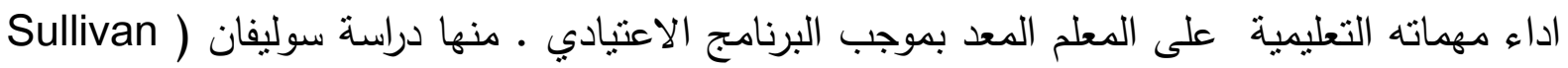

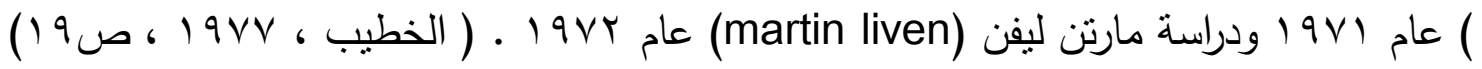

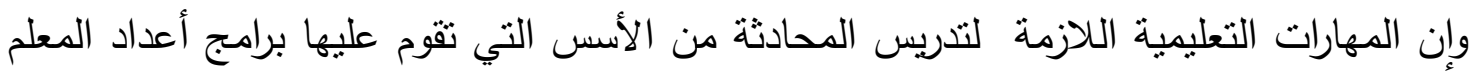

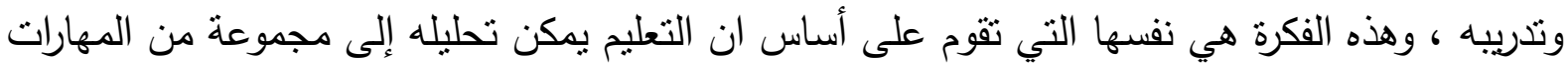

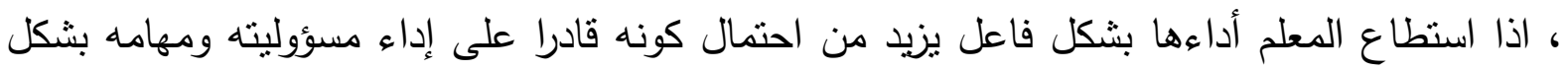

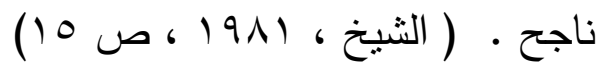

ولذلك من الضروري ان نهتم بتقويمه بصورة دقيقة ومستمرة ،لنساعد على اكتثاف أبعاد شخصيته المهنية

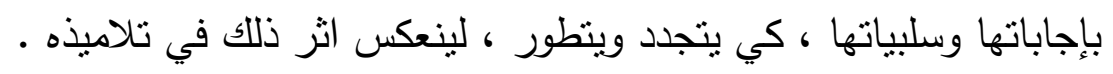

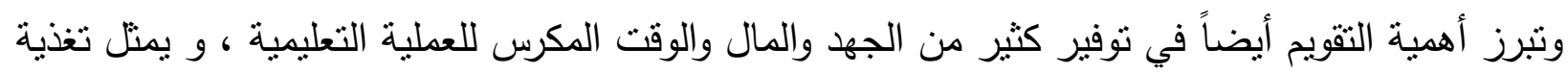

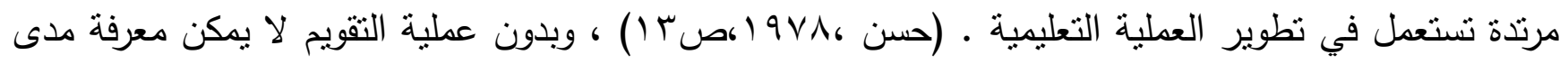
ما حققته العطلية التعليمية من أهداف . ومن هنا وجد الباحث، ان هناك حاجة لإجراء دراسة تنتاول مستوى إداء معلمي اللغة العربية في المرحلة

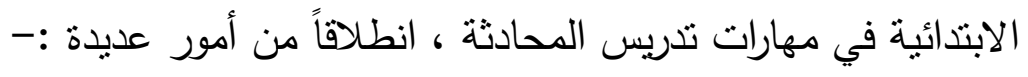

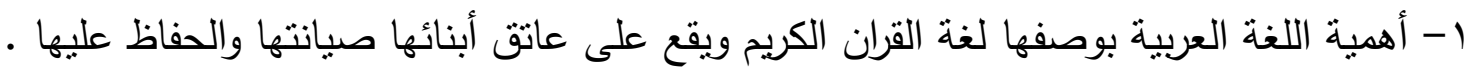

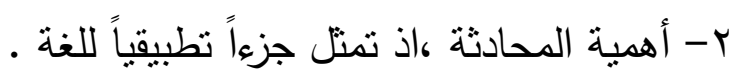

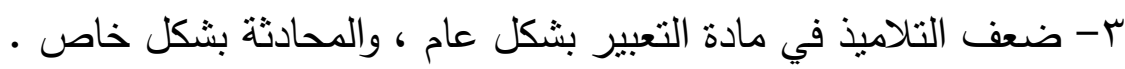
ع - أهمية معرفة مستوى إداء معلمي اللغة العربية في تدريس مهارات المحادثة في المرحلة الابتدائية .

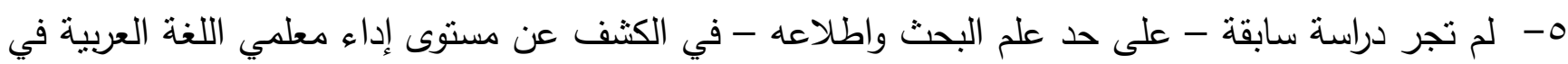
المرحلة الابتدائية في مهارات تدريس المحادثة. 
ج- يمكن ان تفيد هذه الدراسة المشرفين الاختصاصيين من خلال أداة الملاحظة الموضوعية التي أعدها الباحث

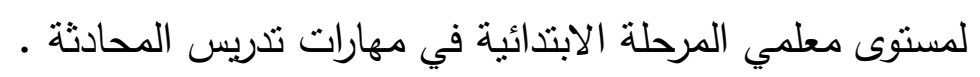

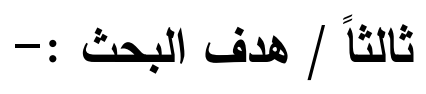

يستهدف هذا البحث معرفة مستوى إداء معلمي اللغة العربية في المرحلة الابتدائية في مهارات تدريس

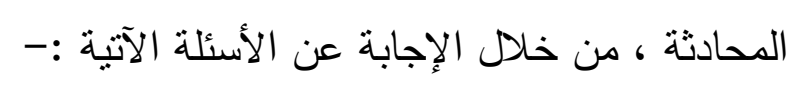

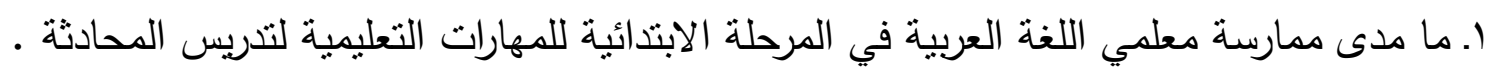

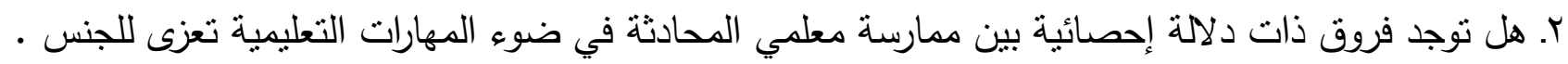

$$
\text { رابعاً / حدود البحث :- يقتصر هذا البحث على :- }
$$

معلمي اللغة العربية الذين يقومون بتدريس المحادثة في المرحلة الابتدائية التابعين للمديرية العامة لتربية

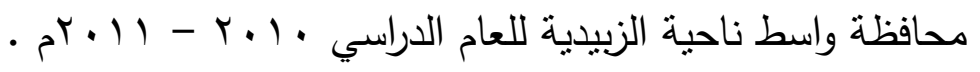

خامساً / تحديد المصطلحات :-

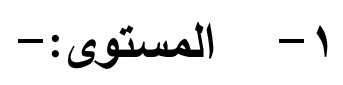

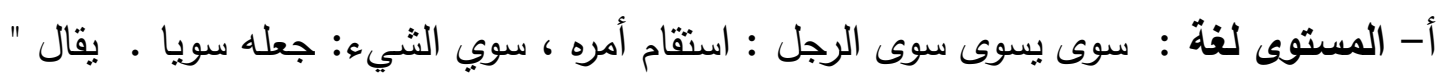

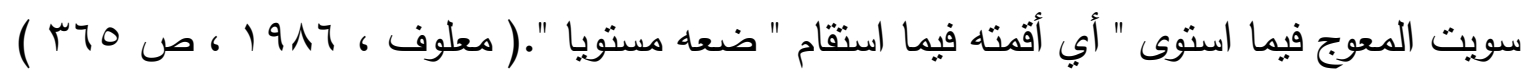

$$
\text { بـ - المستوى اصطلاحاً : عرفه :- }
$$

1- نجار : في قاموس التربية ، بأنه : " الهدف أو الغاية التي بسعى الفرد ، أو الجماعة للوصول

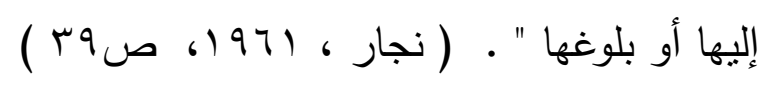




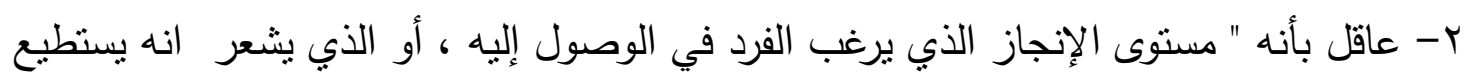

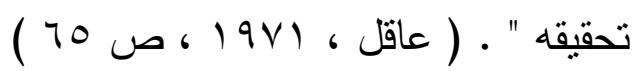

$$
\begin{aligned}
& \text { التعريف الإجرائي للمستوى : }
\end{aligned}
$$

هو بلوغ مقدار معين من الكفاية في تدريس مهارات المحادثة لدى معلمو اللغة العربية في

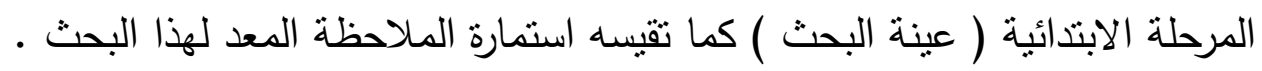

$$
\text { - : المهارة }
$$

أ ـ المهارة لغةٌ : ( وردت في المعجم الوسيط مهارة : أحكمه وصر به حاذقا فهو ماهر ) .

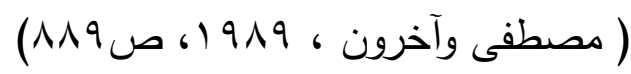

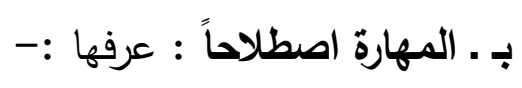

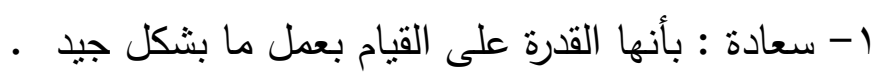

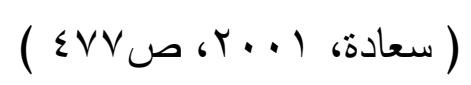

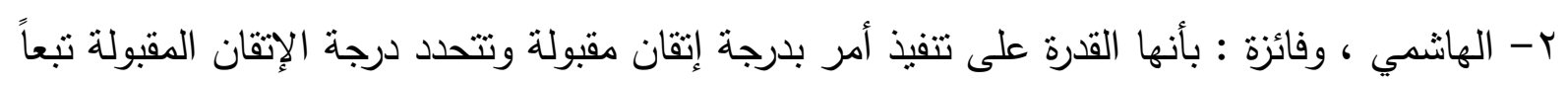

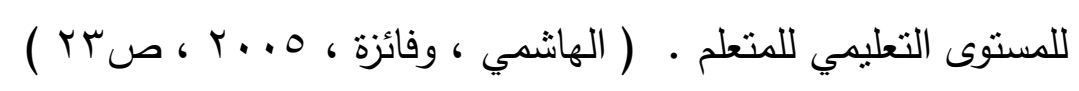

\section{التعريف الإجرائي :-}

عرفها الباحث بأنها ما يمتلكه معلمي اللغة العربية من ممارسات وفعاليات وأنشطة لازمة لتدريس مادة

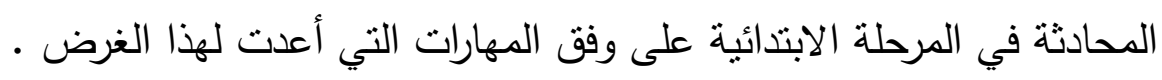




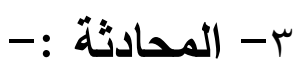

أ ـ المحادثة لغة :-

ورد في تاج العروس (( والحديث ما يحدث به المحدث تحديثاً وقد حدثه الحديث وحدثه به)).

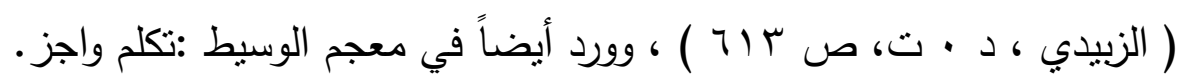

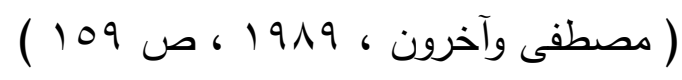

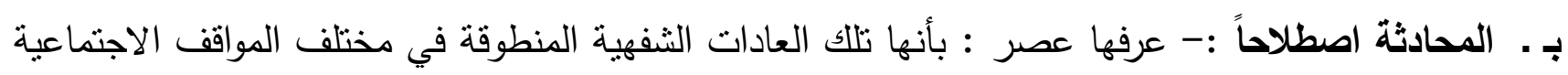

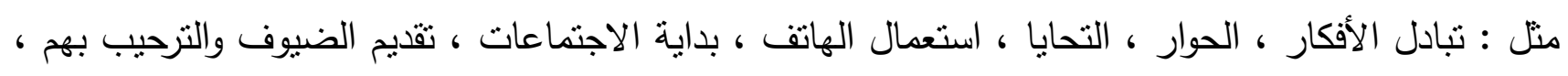

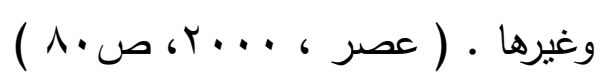

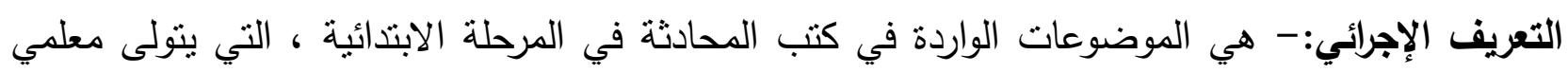

اللغة العربية تعليمها لتلاميذهم . 
دراسات سابقة

الفصل الثاني

اولاً / دراسات سابقة : يعرض الباحث في هذا الفصل قسماً من الدراسات ذات العلاقة بموضوع هذا البحث منها :-

\section{| 1991 - دراسة السبيعي 199}

أجريت هذه الدراسة في العراق ورمت إلى تعرف " تقويم أداء معلمي اللغة العربية في ضوء

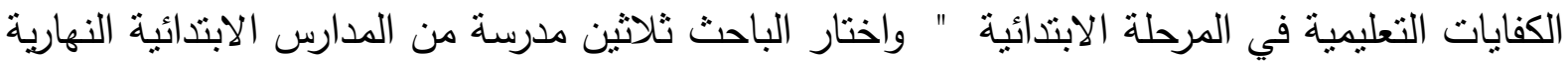

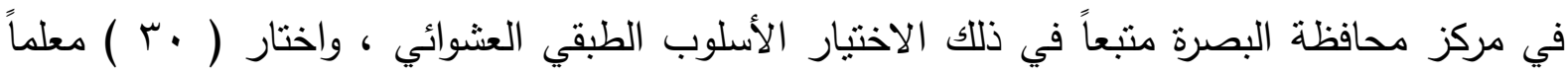

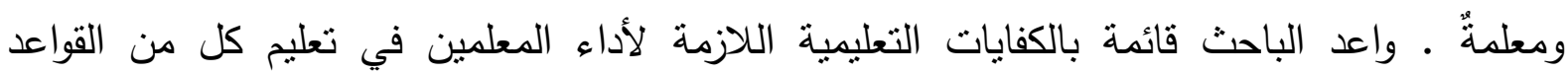
والأنشاء والإملاء والقراءة ـ وطبق الاستمارات الأربع بنفسه عن طريق الملاحظة المباشرة ، وبعد تحليل

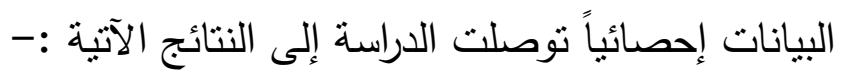
1 - كان أداء معلمي اللغة العربية في تعليم القواعد بشكل عام دون الحد الأدنى من المستوى الدئن

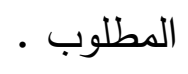

r - كان أداء معلمي اللغة العربية في تعليم مادة الإنثاء بشكل عام ضعيف بموجب المقياس

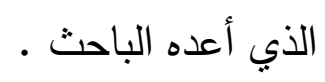

r - كان أداء معلمي اللغة العربية في تعليم مادة الإملاء بشكل عام دون الدد الأدنى من المستوى

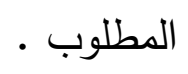

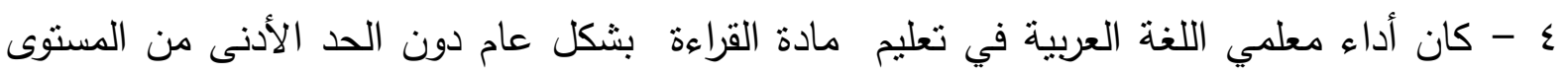

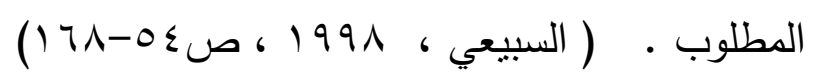

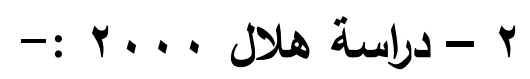


أجريت هذه الدراسة في البحرين ورمت إلى معرفة " الكفايات التدريسية اللازمة لمعلمي اللغة

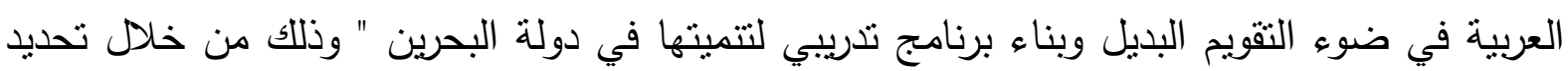

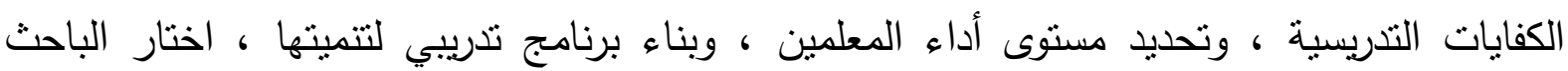

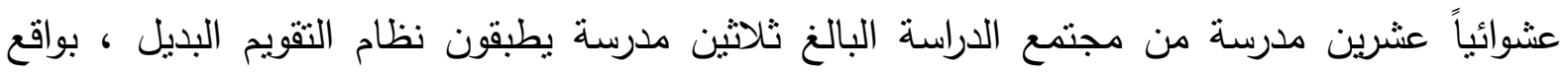

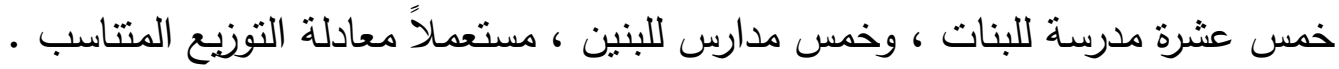

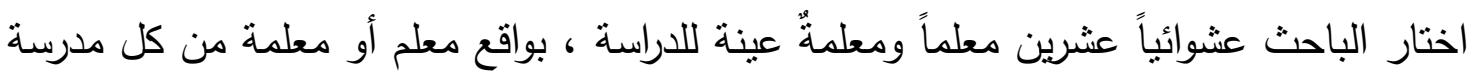

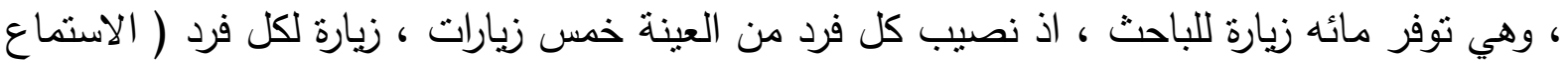

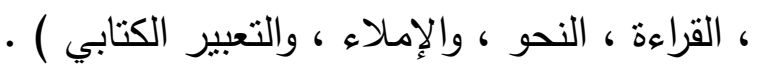

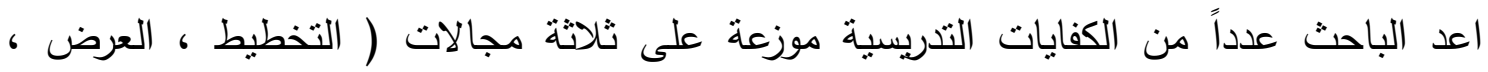

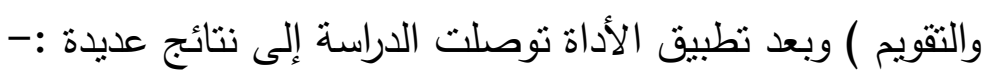

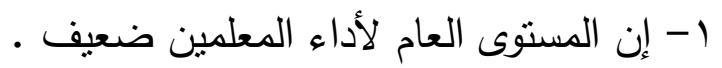

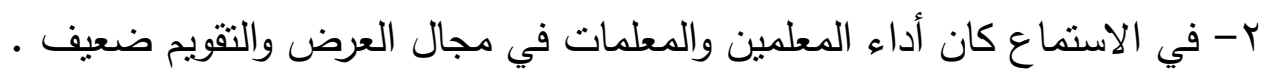

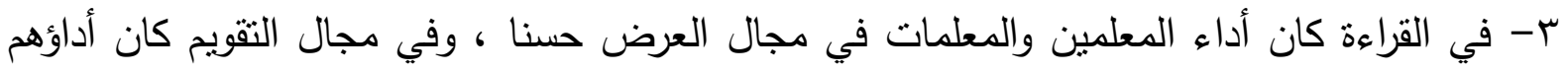
ضعيفا. ع- في النحو كان أداء المعلمين والمعلمات في مجال العرض حسنا ، أما في مجال التقويم فكان أدوأهم ضعيفاً . 0- في الإملاء كان الأداء بشكل عام حسنا في مجال العرض وضعيفا في مجال التقويم .

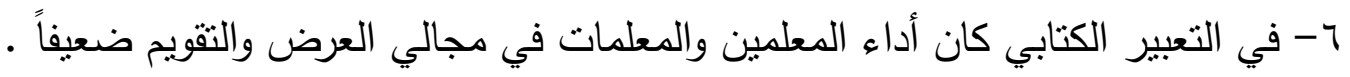

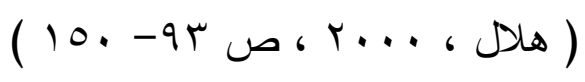

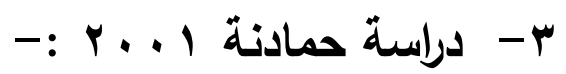


أجريت هذه الدراسة في الأردن ورمت إلى معرفة " تقويم أداء معلمي اللغة العربية في المرحلة

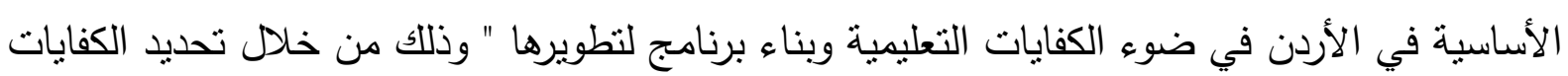

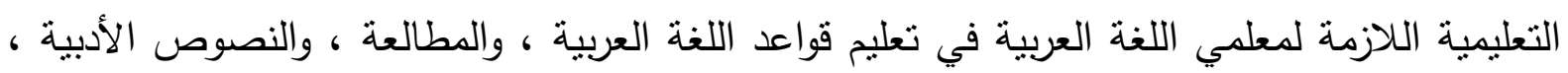

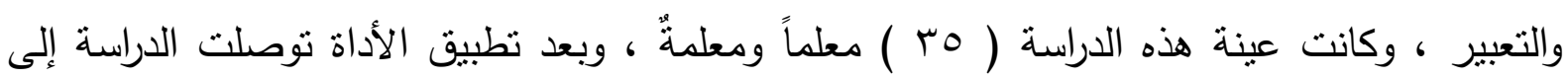

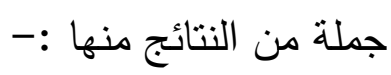
ا- إن أداء معلمي اللغة العربية الذين يدرسون الصفوف الثامن والتاسع والعاثر كان متوسطاً في ضوء الكفايات المعدة .

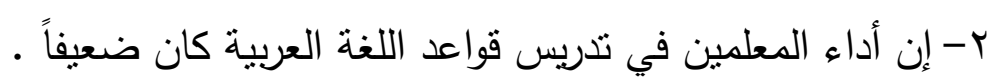

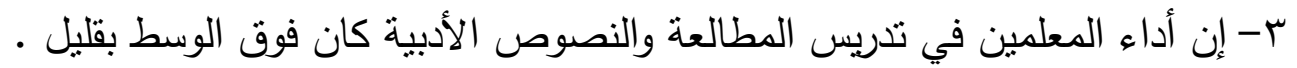

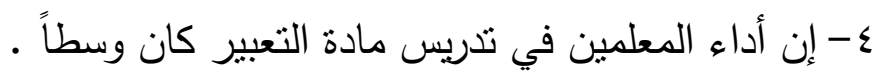

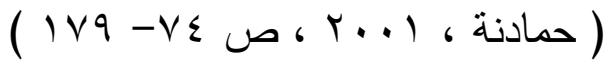

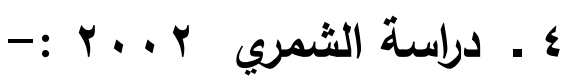

أجريت هذه الدراسة في العراق ورمت إلى معرفة " تقويم أداء معلمي اللغة العربية في تعليم مادة

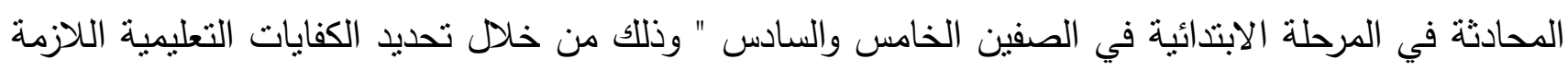

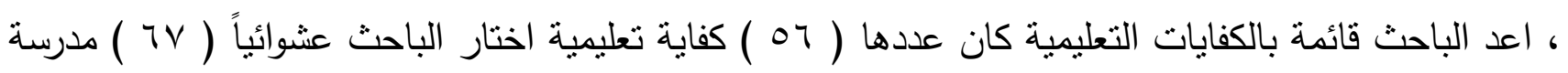

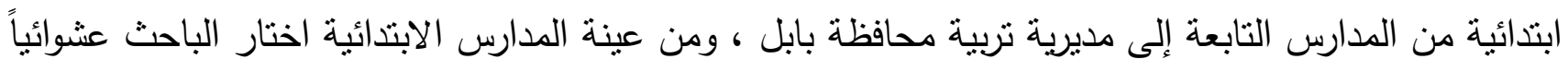

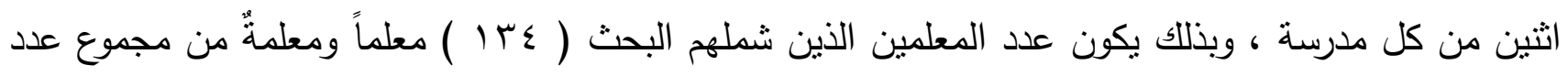

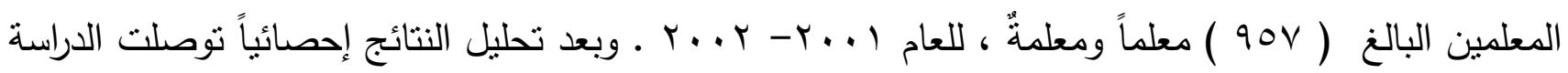
إلى عدة نتائج :1- كان أداء معلمي اللغة العربية في تعليم مادة المحادثة بشكل عام دون الحد الأدنى من المستوى المطلوب في كل المجالات . 
ץ- كان أداء المعلمين حسنا في كفايتين من الكفايات التعليمية الخاصة بتعليم المحادثة هما كفاية يكتب خطة

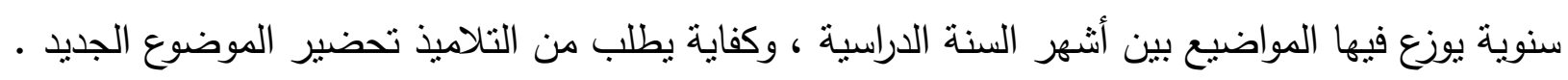

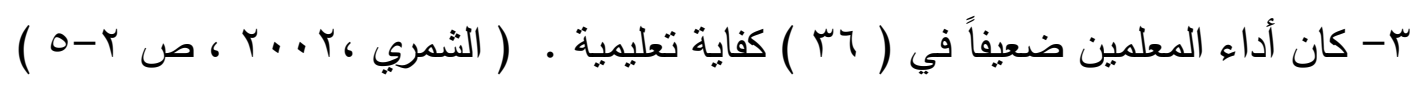

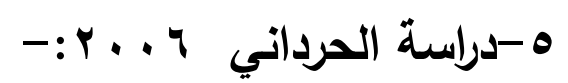

أجريت هذه الدراسة في العراق ورمت إلى معرفة " تقويم اداء معلمي اللغة العربية في ضوء الكفايات

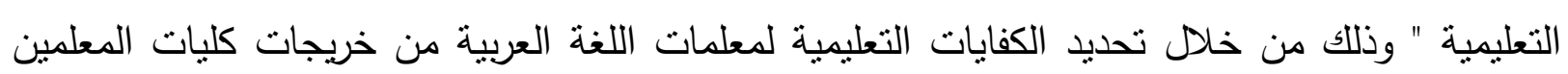

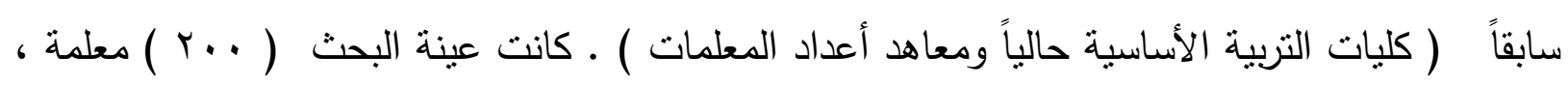

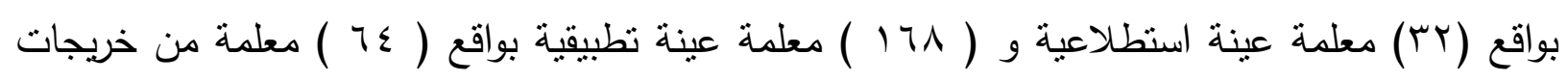

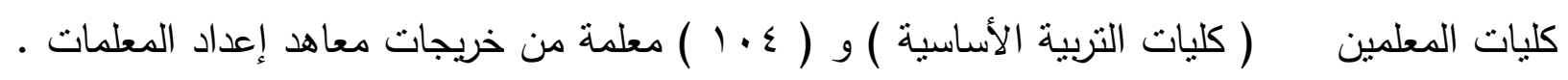

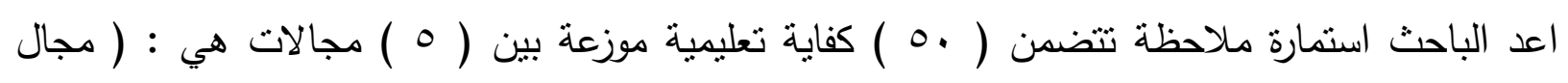

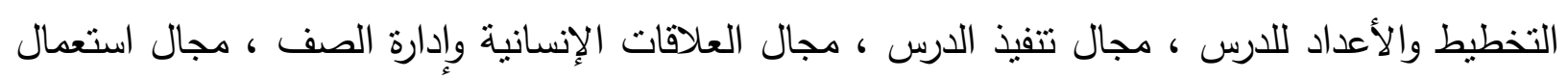

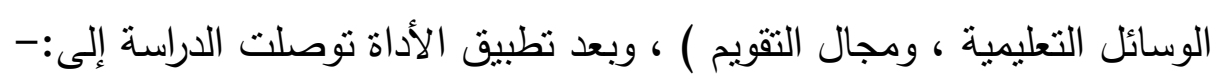

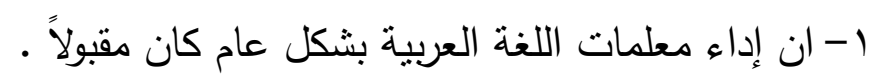

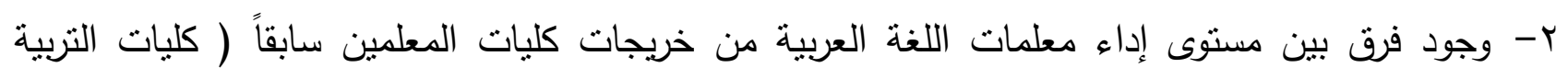

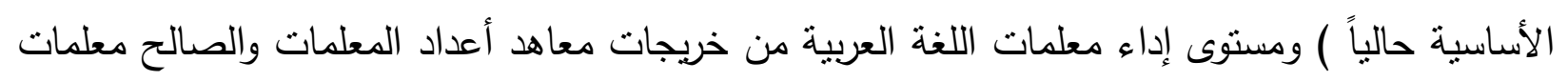

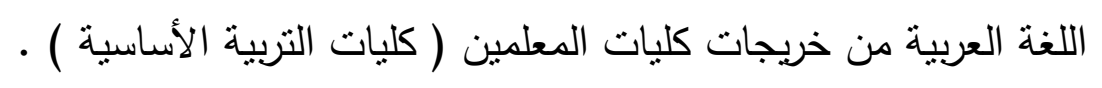

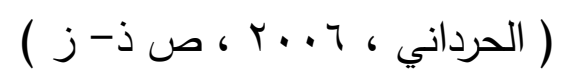

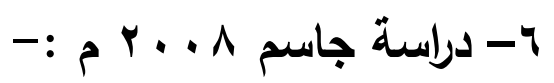

أجريت هذه الدراسة في العراق ورمت إلى معرفة " تقويم كتابي المحادثة العربية لتلادذة المرحلة الابتدائية من

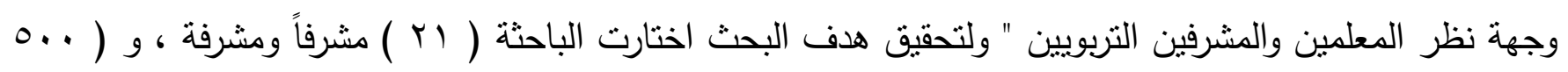

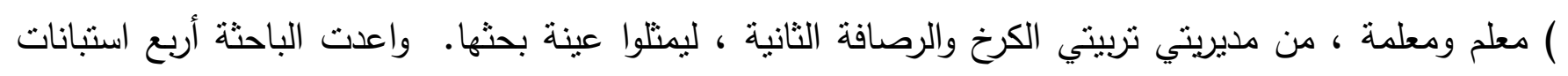

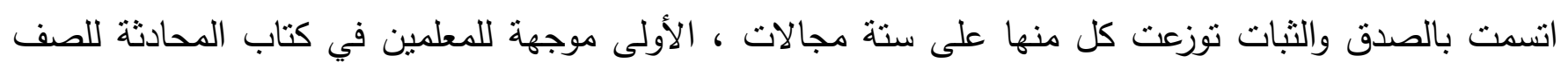


الثالث الابتدائي نكونت من ( • ) فقرة ، والثانية موجهة للمعلمين في كتاب المحادثة للصف الرابع الابتدائي تكونت

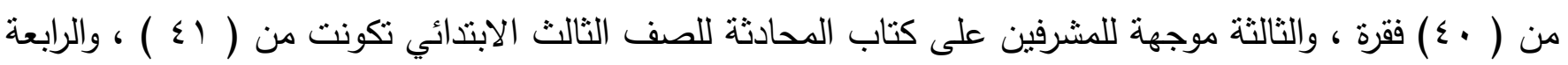
موجهة للمشرفين على كتاب المحادثة للصف الرابع الابتدائي تكونت من ( TV ) فقرة .

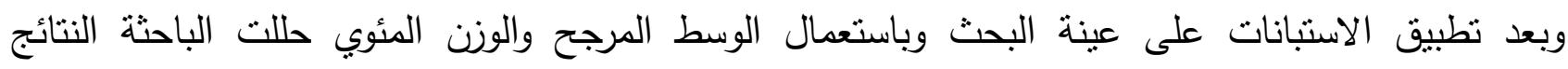

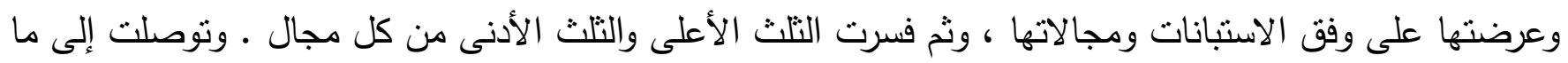
يأني :1 - ان مقدمتي الكتابين لم تبرز أهمية المحادثة ولا توجها المتعلم إلى العناية بالكتاب المدرسي .

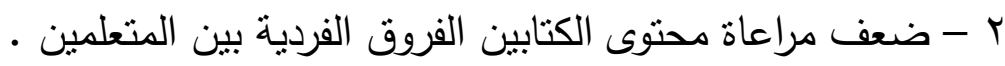

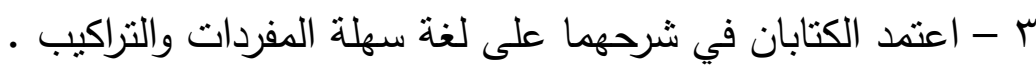

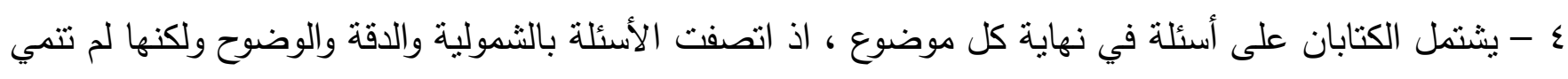

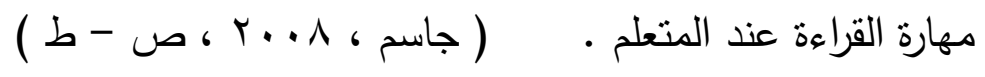

ثانياً ـ الموازنة بين الاراسات السابقة :

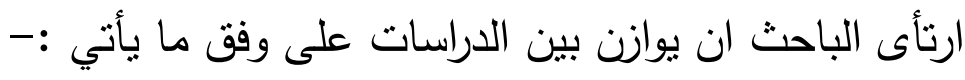

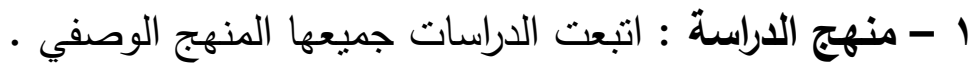

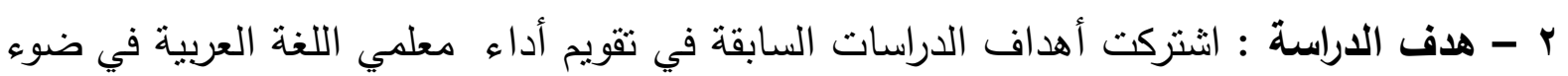
الكفايات التعليمية واكتشاف مواطن الضعف في أدائهر ـ ماعدا دراسة واحدة كانت تقويم كتابي المحادثة العربية للصفين الخامس والسادس الابتدائي .

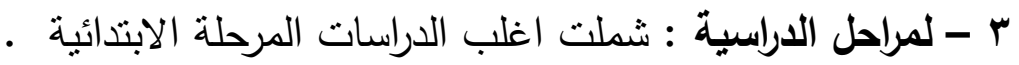

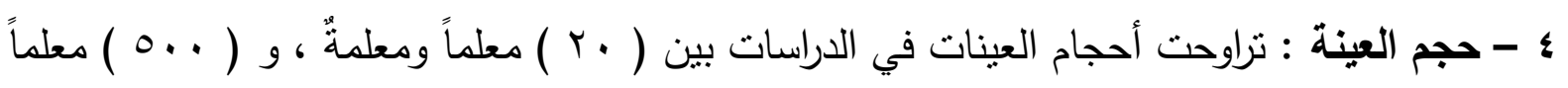

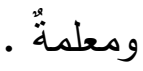
ه - أداة الدراسة : أجمعت الدراسات على استعمال أداة واحدة وهي ( استمارة الملاحظة ) . 
I - الوسائل الإحصائية : تتوعت الوسائل الإحصائية التي استعملها الباحثون في الدراسات السابقة بين : الوسط المرجح والوزن المئوي ومربع كأي • V - نتائج الدراسات : توصلت الدراسات السابقة إلى نتائج مختلفة ومتتوعة اتفقت في غالبيتها على ان ان تقويم أداء المعلمين في ضوء الكفايات كان ضعيفاً بشكل عام ـ ماعدا دراسة واحدة كان مقبولاً . لأل

\section{ثالثاً ـ جوانب الإفادة من الدراسات السابقة :-}

أفاد الباحث من اطلاعه على الدارسات السابقة في عدة أمور ، ويمكن تحديد هذه الإفادة بالنقاط الأثية

ا 1 - تحديد مشكلة هذا البحث وهدفه .

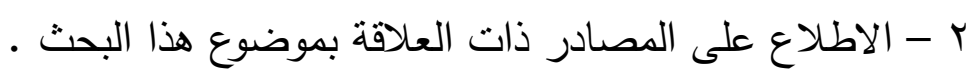

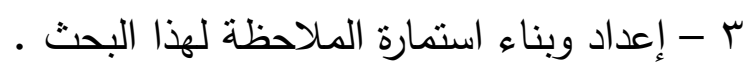
ـ - اختيار الوسائل الإحصائية المناسبة لإجراءات هذا البحأ البحث ونتائجه . 0 - 0 1 - صياغة استتناجات البحث ووضع توصياته ومقترحاته . 


\section{أولاًا / مجتمع البحث وعينته :-}

يتكون المجتمع في هذا البحث من معلمي اللغة العربية للمرحلة الابتدائية التابعين إلى المديرية

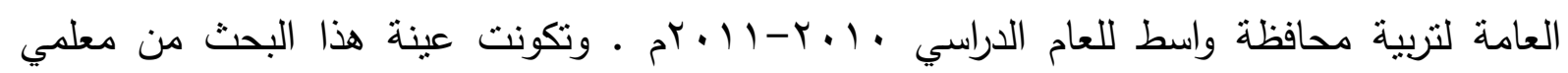

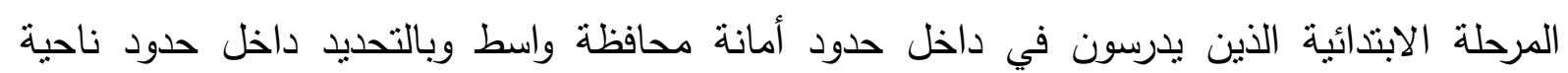

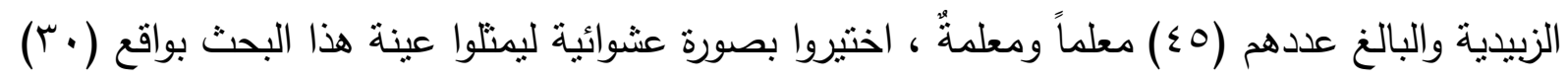

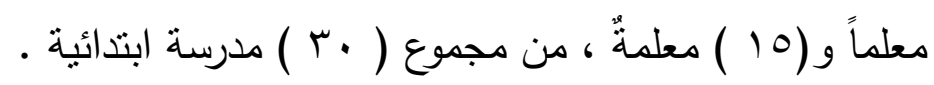

ثانياً / أداة البحث : الاستبانة : لغرض أعداد استبانة تضم عدداً من المهارات التعليمية اللازمة لتنريس المحادثة اتبع الباحث

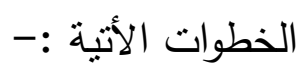
ا- نوجيه استبانة استطلاعيه تحتوي سؤالاً واحداً مفتوحاً إلى ( V ) معلمين و ( V ) معلمات من الذين

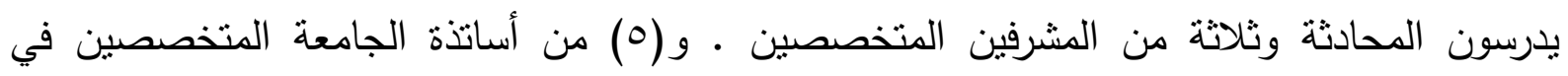

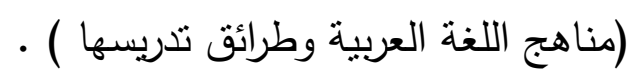

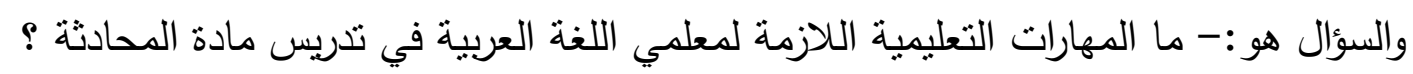

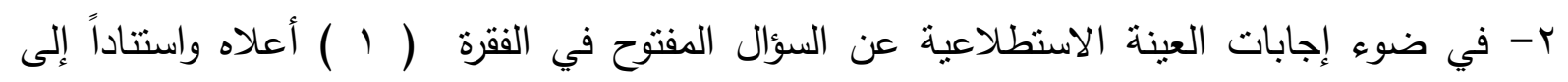

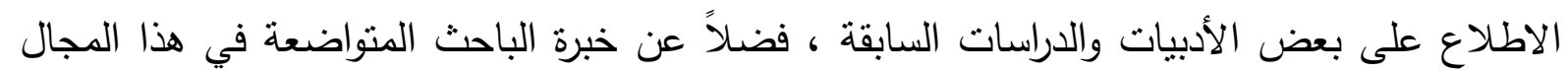
أعد استبانة تكونت من ( الاعلى ) فقرة موزعة على مجالات خمسة هي (مهارات تخطيط الدرس ، مهارات

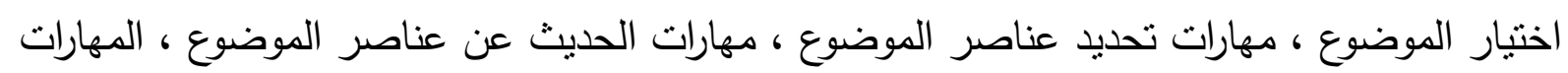

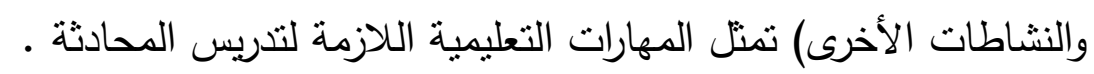


r - عرض الباحث هذه الاستبانة على مجموعة من الخبراء المتخصصين في طرائق تدريس اللغة

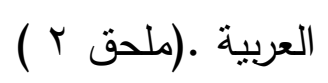

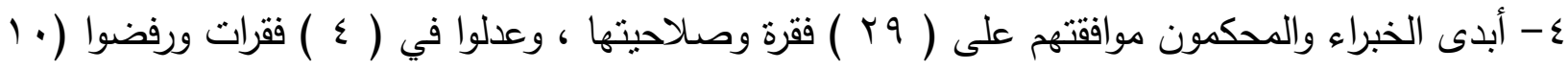

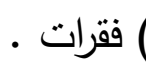
ه - بعد الاستتاد إلى آراء الخبراء والمحكمين أصبحت الاستبانة تتكون من ( س ) فقرة بصيغتها النهائية

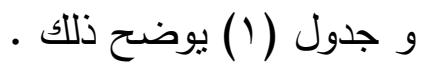

$$
\text { جدول ( ) }
$$

\begin{tabular}{|c|c|c|c|c|c|}
\hline الألشاطات الأخرى & مهارة الحديث عناصر & مهارة تحليد & مهارة اختيار & مهارة تخطيط & المهارة \\
\hline$\wedge$ & $v$ & $r$ & $v$ & $\wedge$ & عدد الفقرات \\
\hline
\end{tabular}

المهارات التعليمية بصيفتها النهائية

צ- لغرض التعرف على ثبات الاستبانة طبقها الباحث على ( • (1 ) من المعلمين والمعلمات الذين يدرسون

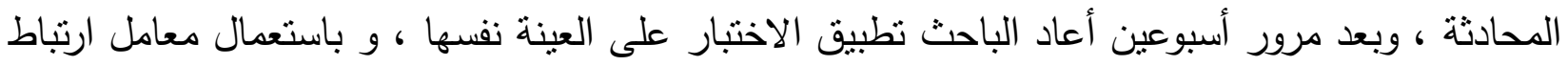

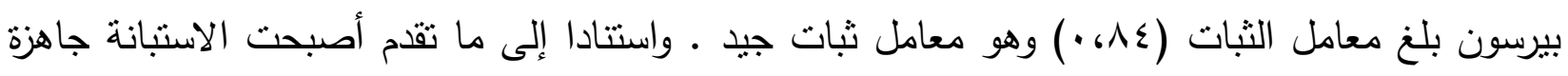
بصورتها النهائية ـ ملحق (1) بعلمعان

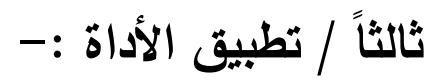

طبق الباحث أداة بحثه على معلمي اللغة العربية (عينة البحث ) في خمسة عشر يوماً ابتداءً من يوم الأحد 


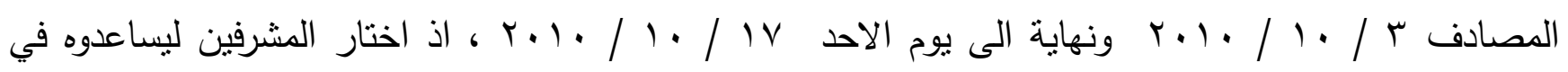

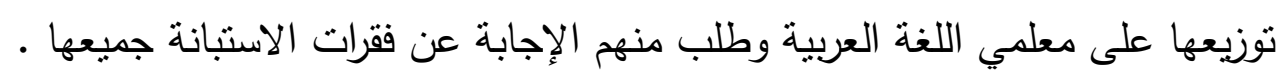

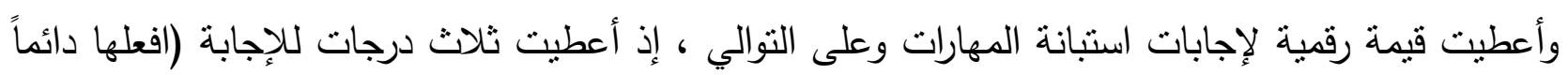

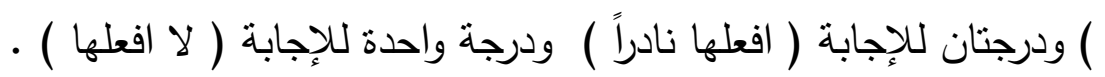

رابعاً / الوسائل الإحصائية :- استعمل الباحث الوسائل الإحصائية المناسبة للبحث :-

1- معامل ارتباط بيرسون : استعملت هذه الوسيلة لحساب معامل الثبات .

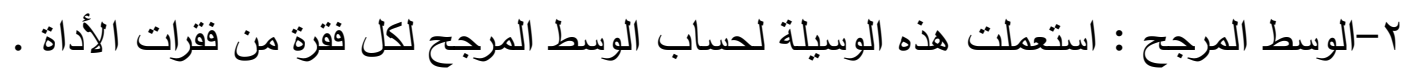

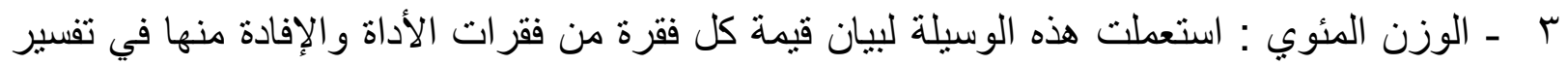
النتائج. ؟ - الاختبار التائي T. test : استعملت هذه الوسيلة لحساب الفرق بين المعلمين والمعلمات في استعمال مهارات تدريس المحادثة . 
يعرض الباحث في هذا الفصل النتائج التي توصل إليها بعد تطبيق استمارة ملاحظة أداء معلمي

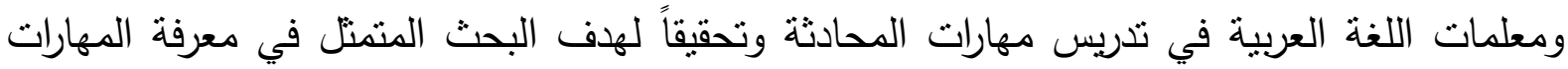
التعليمية اللازمة لتدريس المحادثة ، نم التوصل إلى النتائج الآتية :1- للإجابة عن السؤال الأول (ما مدى ممارسة معلمي اللغة العربية في المرحلة الابتدائية للمهارات التعليمية لتدريس المحادثة ؟ ) ، حيث تم حساب الوسط المرجح و والوزن المئوي لكل مهارة من مهارات

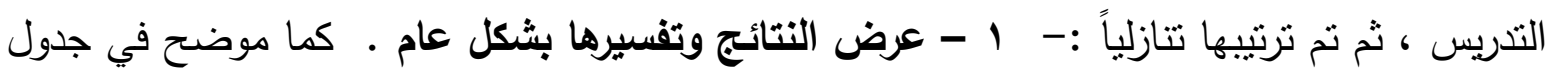

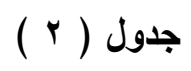

المهارات التعليمة مرتبة ترتيباً تنازلياً

\begin{tabular}{|c|c|c|c|}
\hline المئوي\% & المرجـح & 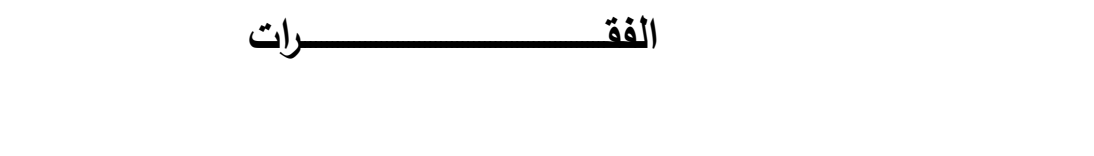 & $ت$ \\
\hline 9\{ & $r, A Y$ & ربط الموضوع بييئة الطالب . & 1 \\
\hline $91, \pi$ & $r, Y \varepsilon$ & يكتب الموضوع أو الموضوعات على السبورة بخط واضح وترتيب منظم . & r \\
\hline 9 . & $r, Y \cdot$ & وضع بداية للحديث ونهاية له . & $r$ \\
\hline NT & $r, 01$ & يقدم موجزا عن طبيعة الموضوع · & $\varepsilon$ \\
\hline$\Lambda \varepsilon$ & & يصوغ الأهداف الخاصة للارس بصورة واضحة . & 0 \\
\hline r & r,o & تشجيع الرغبة في التحدث . & 7 \\
\hline ז & $r, \Sigma 9$ & يبين الثواهد التي يستعملها في الموضوع . & $\checkmark$ \\
\hline$\wedge r, 74$ & $r, 乏 \wedge$ & يطلب من بعض التلاميذ المتميزين التحدث عن عناصر الموضوع • & $\wedge$ \\
\hline
\end{tabular}




\begin{tabular}{|c|c|c|c|}
\hline 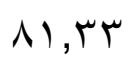 & $r, \Sigma \varepsilon$ & |ربط أفكار الحديث ببعضها . & 9 \\
\hline$\vee 9,77$ & $r, r q$ & يحسن اختيار الثواهد موضعا وموضوعا & 1 . \\
\hline 19 & $r, r v$ & | اذكر الأفكار الرئيسية للحديث . & 11 \\
\hline vq & $r, r v$ & | التزكز على الفكرة المعينة . & it \\
\hline Vד, & $r, r q$ & أمهر للموضوع المختار بإيجاز مراعيا سلامة اللغة في الحديث والكتابة . & ז \\
\hline VT, Tr & $r, r q$ & الحاجة إليه . اندفاع الطلبة نحو الموضوع الذي له صلة بحياتهم اليومية مبينا & $1 \leq$ \\
\hline V7 & $r, r \wedge$ & يقوم أخطاء الطلبة الفكرية واللغوية بأسلوب مشجع لا محبط . . & 10 \\
\hline 77 & $1, \wedge 9$ & 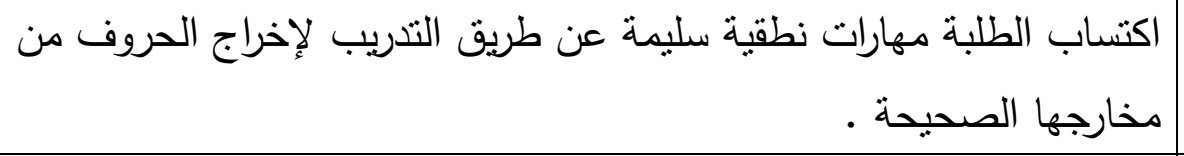 & 17 \\
\hline $7 \varepsilon$ & $1,9 \leq$ & خلق مواقف تعليمية تتجع الطلبة على التحدث بحرية عما يجول في أنفسهم & iv \\
\hline Tr & $1, \wedge 7$ & يذكر الطلبة ان الإجابة عن الأسئلة تمنل عنصراً من عناصر الموضوع • & 11 \\
\hline $7 \cdot, 77$ & $1, \wedge r$ & |الإعداد المسبق للحديث . . & 19 \\
\hline ov & $1, \mathrm{~V}$ & القدرة على جذب انتباه المستمعين • & r. \\
\hline $0 \leqslant, r \mu$ & $1, \pi$ & يكلف الطلبة تهيئة موضوعات خطابية تلقى أيام الخميس والمناسبات . & r) \\
\hline 0 . & 1,0 & | اعتماد النشاطات التي يؤديها الطلبة لأنها تزيد مهارات التحدث . & r \\
\hline 0. & 1,0 & | اكتب توجيهات للطلبة حول كتابة الموضوع • & r \\
\hline$\varepsilon \Lambda, r \mu$ & $1, \leqslant 0$ & | أبين الآلية التي يعرض بها الموضوع • & $r \varepsilon$ \\
\hline$\{V, \pi\}$ & $1, \varepsilon r$ & اعد الوسائل التعليمية المناسبة للدرس • & ro \\
\hline
\end{tabular}




\begin{tabular}{|c|c|c|c|}
\hline$\leqslant \vee$ & $1, \S 1$ & استعمال الحواس في إثتاء الحديث للتوضيح • & ru \\
\hline$\varepsilon\urcorner$ & $1, \Pi \wedge$ & تغير نبرة الصوت . & rV \\
\hline$\varepsilon 0, r$ & $1, \mathrm{r}$ & اكتب على السبورة الشواهد التي وردت بشكل منظم إمام العنصر الذي يلائمه & rᄉ \\
\hline ミ) & $1, r$ & امتلاك المعلم تقافة عامة مع القابلية على التحدث بلغة عربية سليمة وتعويد الطلبة & rq \\
\hline re & 1,9 & اكتب العنصر على السبورة بترتيب يسمح بكتابة الشواهد الخاصة بكل عنصر أمامه & r. \\
\hline 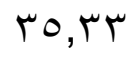 & 1,7 & احدد بمشاركة الطلبة عنوانا جانبيا لكل عنصر من عناصر الموضوع • & ו \\
\hline ro & 1,0 & اعتماد التمثيل والخطابة والمناظرة . & rt \\
\hline 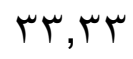 & 1 & اعتماد الإذاعة المدرسية . & r \\
\hline
\end{tabular}

\section{: تقسير النتائج}

يتضح من الجدول ( r ) إن الوسط المرجح والوزن المئوي لمهارات معلمي المرحلة الابتدائية في

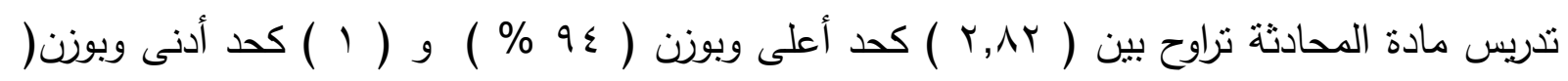
rr,rr \%) ، وعند مقارنتهما مع الوسط الفرضي للمقياس والذي يبلغ ( r) وجد إن هناك ( 10 ) فقرة ارتقت فيها مهارة المعلمين إلى المستوى المطلوب حيث كان الوسط المرجح لها اكثر من الوسط الفرضي

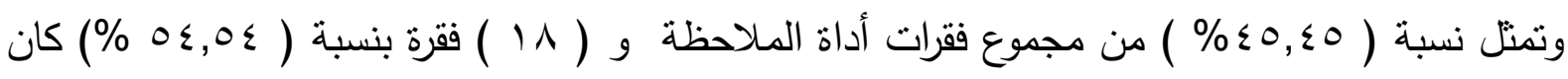
الوسط لمرجح لها دون الوسط الفرضي وبذلك لم ترنق إلى المستوى المطلوب . وعلى هذا سيفسر الباحث الفقرات الخمس الأولى والفقرات الخمس الأخيرة من فقرات استمارة الملاحظة : 


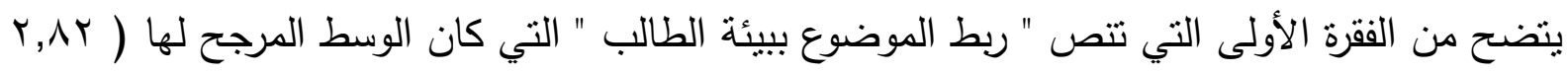

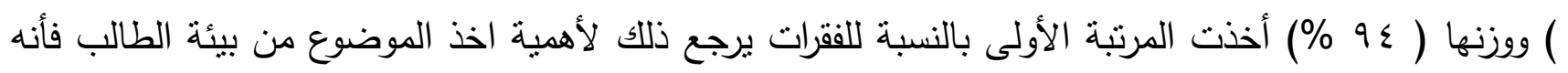

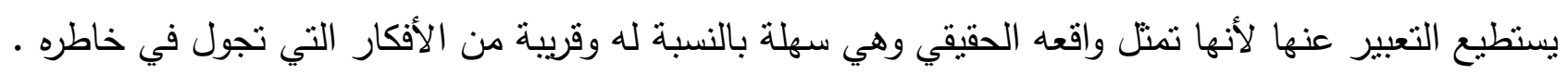

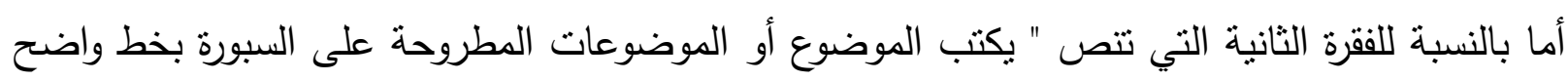

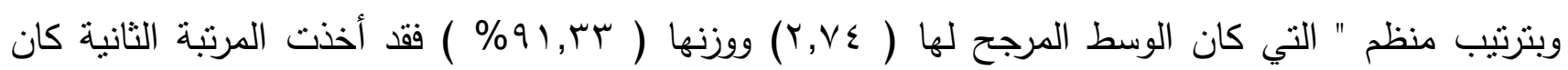

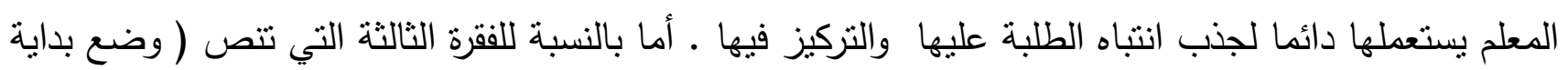

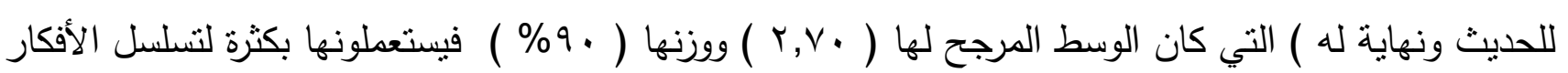

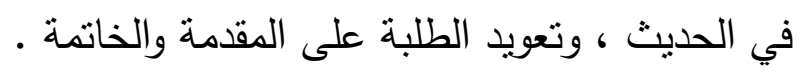

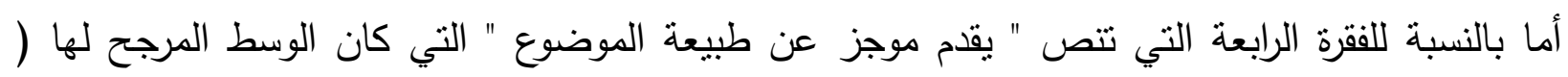

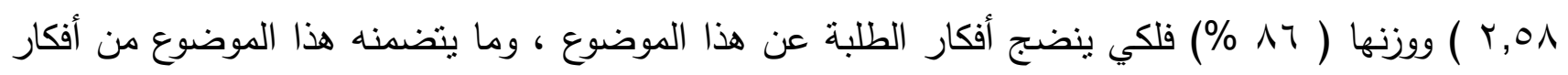
ومعلومات عامة . أما الفقرة الخامسة التي تتص " يصوغ الأهداف الخاصة للارس بصورة واضحة " التي كان الوسط المرجح

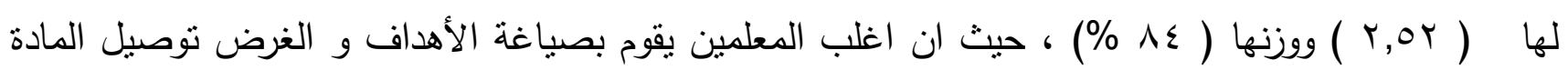

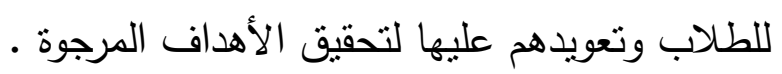

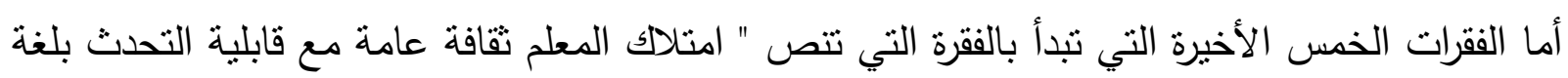

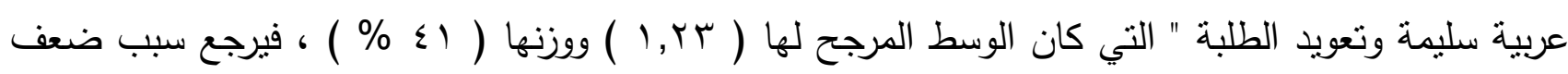

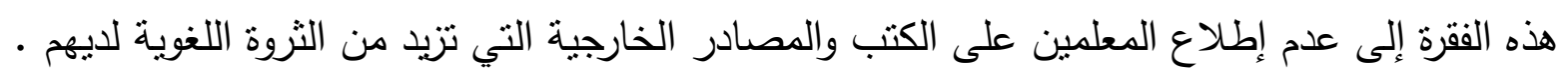

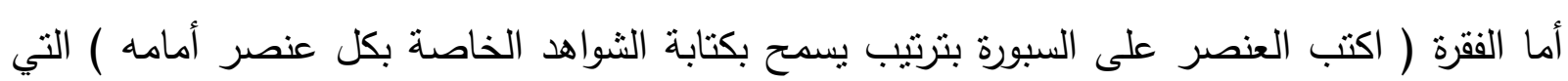
كان الوسط المرجح لها ( 1,9 ) ووزنها ( TV \% \% ) ، فضعف هذه الفقرة لعدم استعمال المعلم الوسائل التعليمية

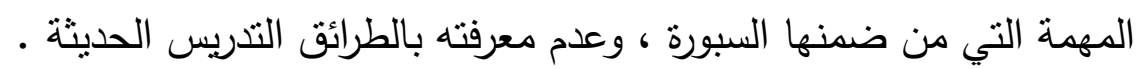

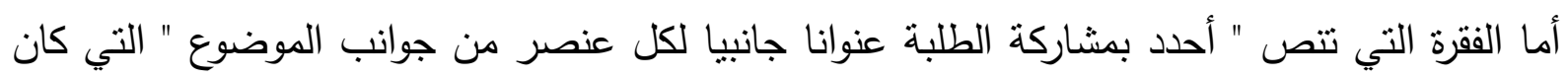

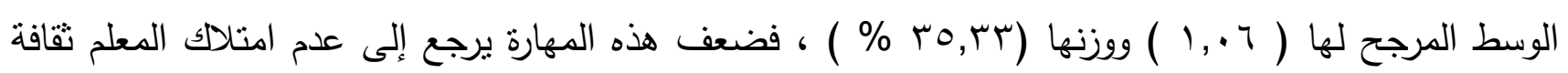

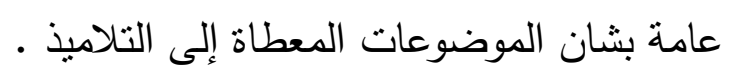


أما الفقرة " اعتماد التمثيل والخطابة والمناظرة " التي كان وسطها المرجح ( فهذه غير موجودة أساساً لأن المعلم لا يسنطيع أن يدرس الطالب المحادثة على شكل تمثيل.

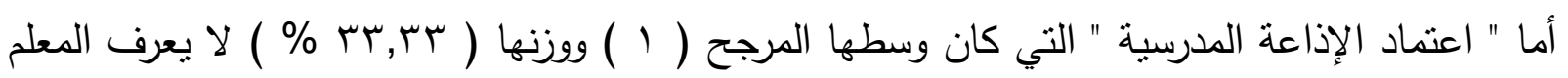
إن الإذاعة لها دور بارز في تطوير الثروة اللغوية عند التلاميذ ـ وبصورة عامة فأن نجاح المبحة المعلم في مهنته يتوقف إلى حد كبير على إعداده المهني العلمي .

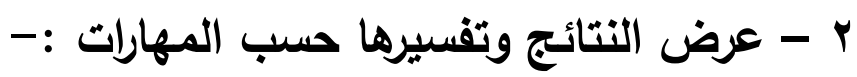
جدول (r)

يبين هذا الجدول مهارات التدريس حسب اهيتها

\begin{tabular}{|c|c|c|c|c|c|c|c|c|c|}
\hline$\wedge$ & $v$ & 7 & 。 & $\varepsilon$ & $r$ & $r$ & 1 & الرتبة & \\
\hline$\varepsilon$ & $r$ & ○ & 7 & $\wedge$ & $r$ & 1 & $v$ & رقم الفقرة & \multirow{2}{*}{ المهارة الاولى } \\
\hline \multirow[t]{7}{*}{1,0} & $1, \varepsilon r$ & $1, \leqslant 0$ & $1, \wedge r$ & $r, r q$ & $r, \leqslant r$ & $Y, O r$ & $r, v$. & الوسط المرجح & \\
\hline & $v$ & 7 & 。 & $\varepsilon$ & $r$ & r & 1 & الرتبة & \multirow{3}{*}{ المهارة الثانية } \\
\hline & 0 & v & $\varepsilon$ & 7 & $r$ & 1 & $r$ & رقم الفقرة & \\
\hline & $1,9 \leq$ & $r, r q$ & $r, r q$ & $r, r V$ & $r, 0 \wedge$ & $Y, V \leq$ & $r, \wedge r$ & الوسط المرجح & \\
\hline & & & & & $r$ & $r$ & 1 & الرتبة & \multirow{3}{*}{ المهارة الثالثة } \\
\hline & & & & & r & $r$ & 1 & رقم الفقرة & \\
\hline & & & & & $1, .7$ & 1,9 & 1,19 & الوسط المرجح & \\
\hline
\end{tabular}




\begin{tabular}{|c|c|c|c|c|c|c|c|c|c|}
\hline & $v$ & 7 & 0 & $\varepsilon$ & $r$ & r & 1 & الرتبة & \multirow{3}{*}{ المهارة الرابعة } \\
\hline & v & $r$ & $\varepsilon$ & 7 & ○ & 1 & $r$ & رقم الفقرة & \\
\hline & $1, \pi 4$ & $1, \wedge 9$ & $r, r q$ & $r, \leqslant \leqslant$ & 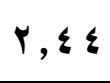 & $r, \leqslant \Lambda$ & $r, 0$ & الوسط المرجح & \\
\hline$\Lambda$ & v & 7 & 0 & $\varepsilon$ & $r$ & r & 1 & الرتبة & \multirow{3}{*}{ المهارة الخامسة } \\
\hline 1 & 7 & r & $\varepsilon$ & $r$ & $\wedge$ & v & 0 & رقم الفقرة & \\
\hline 1 & $1, .7$ & $1, r \mu$ & $1,\{1$ & $1, \varepsilon r$ & 1,0 & r, & $1, v 1$ & الوسط المرجح & \\
\hline
\end{tabular}

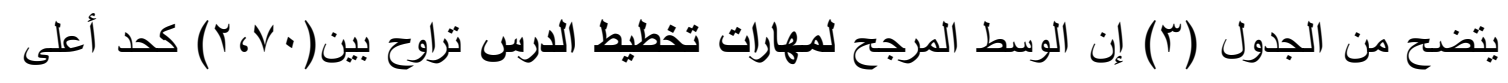

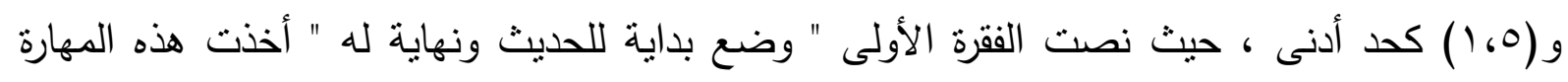

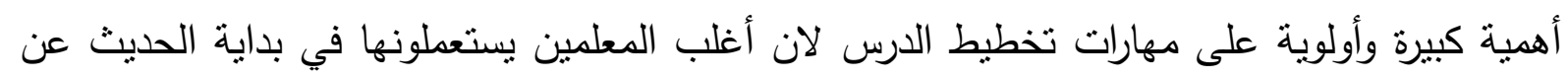

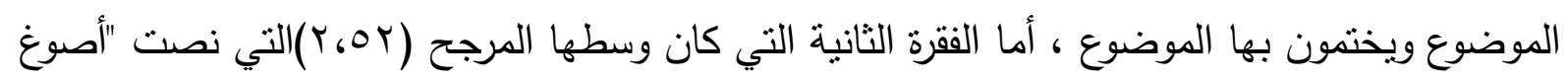

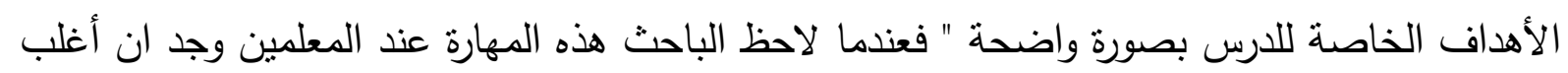

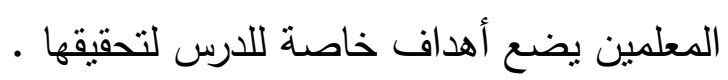

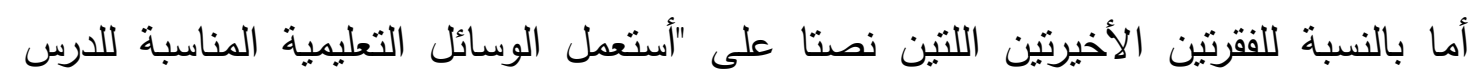

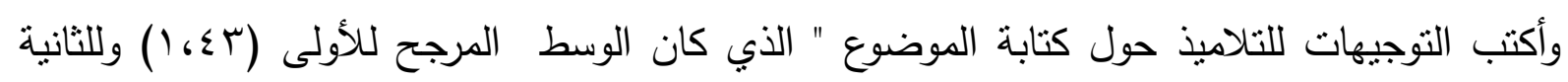

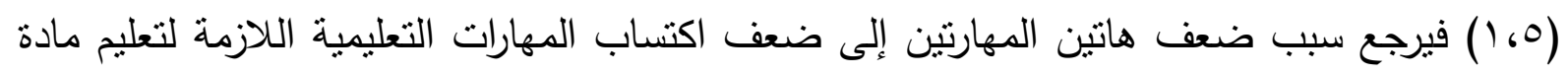

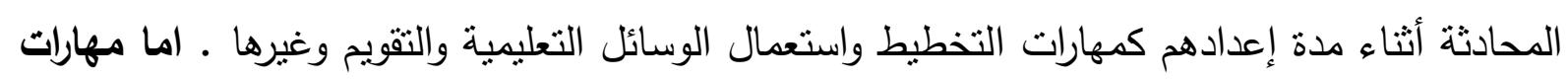

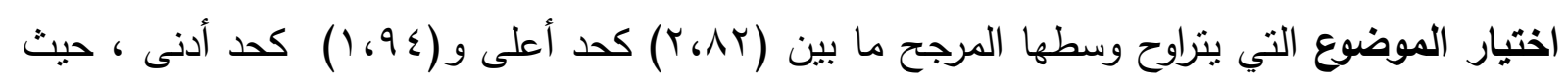


نصت الفقرة الأولى " ربط الموضوع بييئة الطالب " ان هذه المهارة تتوقف على تقريب الفكرة المعينة لدى

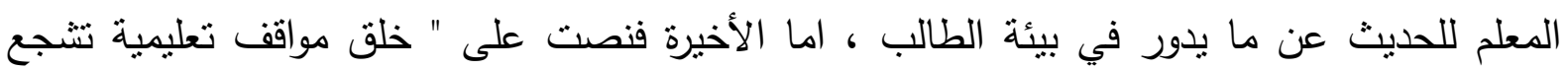

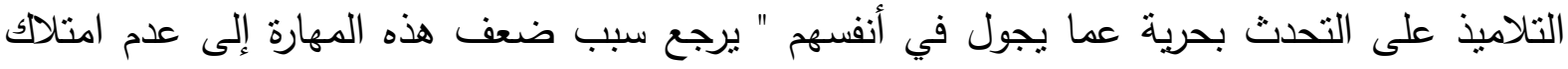

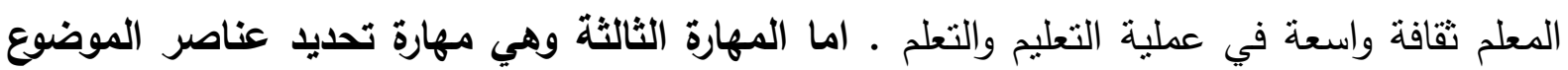

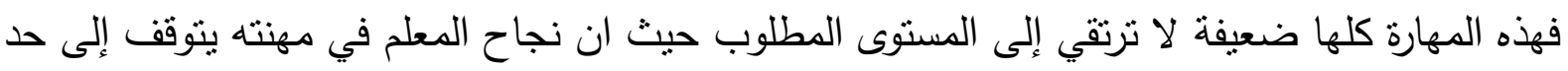

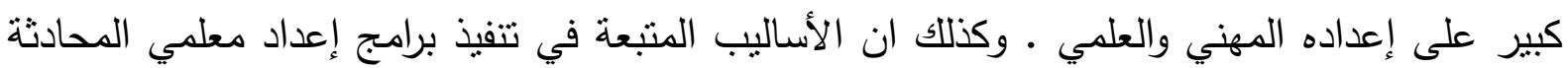
يركز على الجانب المعرفي فقط وإهمال الجوانب الأخرى كتتمية التفكير العلمي والمهارات العقلية ـ اما المهارة الرابعة التي هي الحديث عن عناصر الموضوع التي كان وسطها المرجح يتراوح ما بين (Y.0)

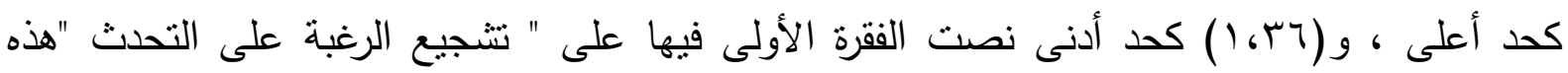

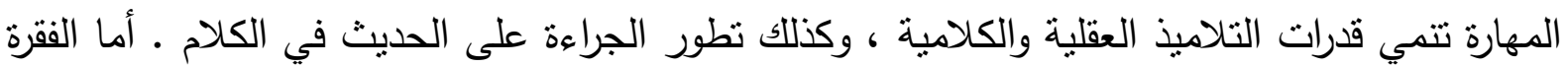

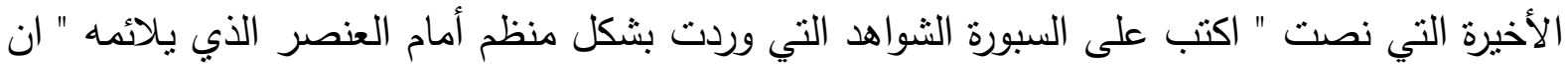
برنامج أعداد معلمي المحادثة لم ينجح بشكل واضح وكبير في تعليم التلاميذ الطرائق التدريسية المناسبة

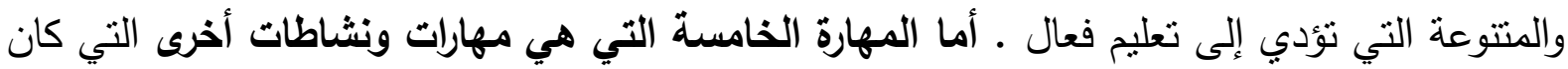

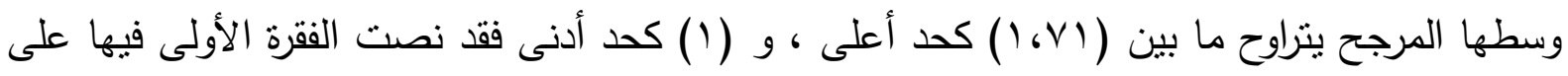
" القدرة على جذب انتباه المستمعين " والفقرة الأخيرة التي تضمنت " اعتماد الإذاعة المدرسية " أما الفقرة الأولى فيعود ضعفها إلى قلة الدورات التدريبية لمعلمي المحادثة وضعف هذه الدورات في إكساب المعلمين المهارات التعليمية اللازمة ، هذا من جهة ومن جهة أخرى قد يعود إلى ضعف متابعة المشرفين

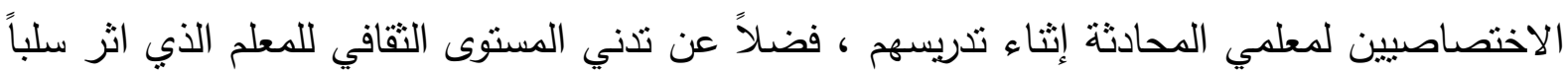

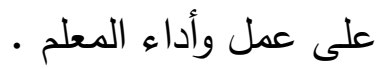
Y_ للإجابة عن السؤال الثاني(هل توجد فروق ذات ذاد دلالة إحصائية بين المعلمين والمعلمات في

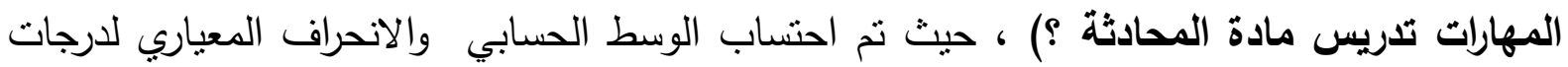
معلمي ومعلمات المحادثة. ثم استعمال الاختبار التائي t.test للكثف عن وجود فروق ذات دلالة

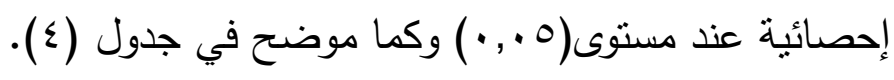


جدول (飞)

المتوسط الحسابي والانحراف المعياري والقيمة التائية لدرجات معلمي ومعلمات المحادثة

\begin{tabular}{|c|c|c|c|c|c|c|}
\hline قالجدولية (ت) & قالمحسوية (ت) & الحرجة & المعياري الانحراف & الحسابي & العدد & الجنس \\
\hline \multirow[t]{2}{*}{$r_{6} \cdot r_{1}$} & \multirow[t]{2}{*}{$1.7 \mathrm{~V}}$. & \multirow[t]{2}{*}{$\varepsilon r$} & r r ro & NEG YO & r. & ذكر \\
\hline & & & Y1.17 & A. ${ }^{\prime} r$. & 10 & أنثى \\
\hline
\end{tabular}

يتضح من الجدول أعلاه لا نوجد فروق ذات دلالة إحصائية بين المعلمين والمعلمات في استعمال

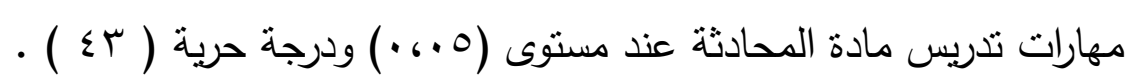

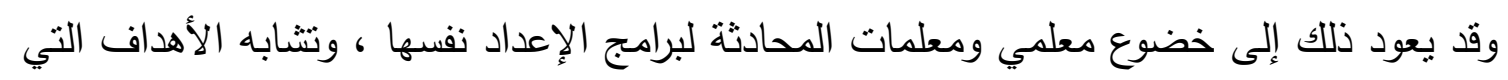

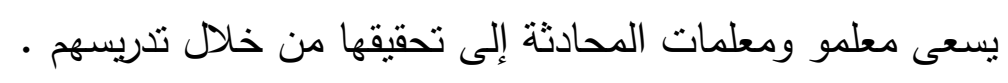

$$
\text { التوصيات : يوصي الباحث بما يأتي :- }
$$

1- ضرورة استعمال المهارات التعليمية في تدريس المحادثة لما لها من آثر في تحقيق أهداف المادة .

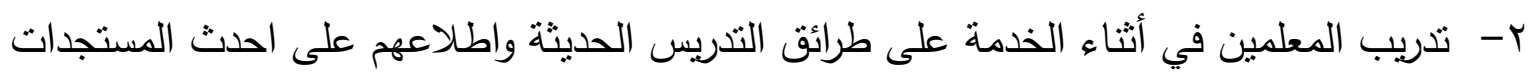

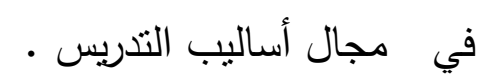

r- تضمين مناهج ومقررات الأعداد المهني للطلبة في المعاهد والكليات الأساسية أساليب المهارات التعليمية. 


$$
\text { المقترحات : يقترح الباحث إجراء دراسات نتتاول ما يأتي :- }
$$

1 - دراسة تكثثف واقع تدريس المحادثة في المرحلة الابتدائية .

r - دراسة مشابهة لهذه الدراسة لكن مع فرع آخر من فروع اللغة العربية .

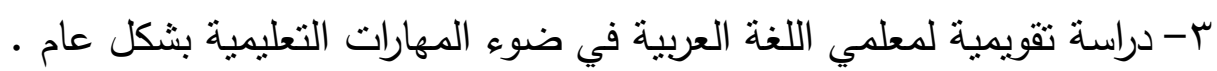




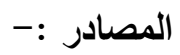

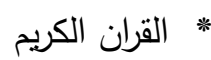

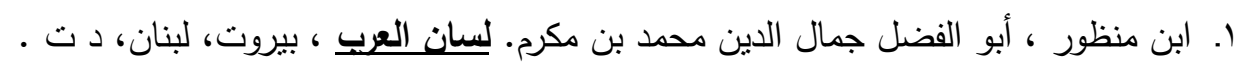

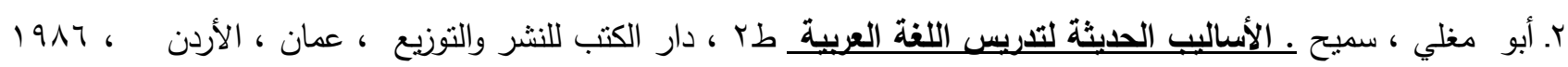

r- الأمين ،شاكر محمود وآخرون ،طرائق تلريس المواد الاجتماعية للصفين الرابع والخامس لمعاهـ أعداد المطلين،

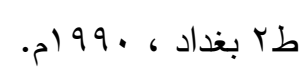

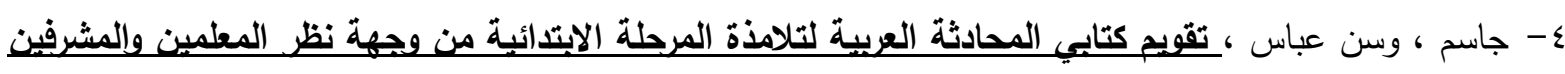

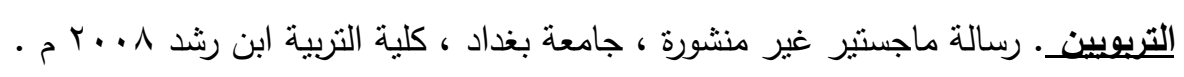

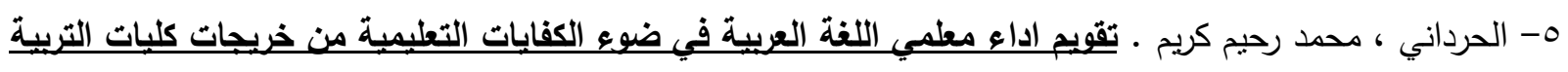

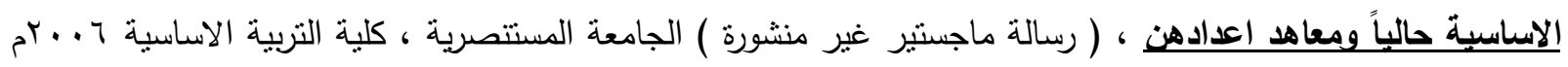

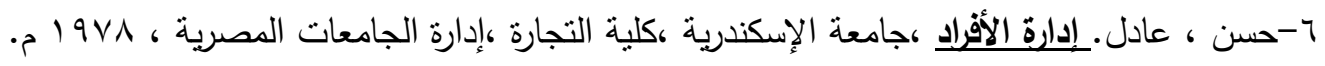

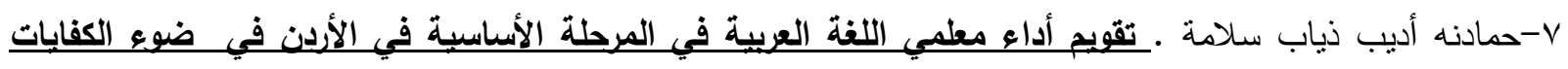

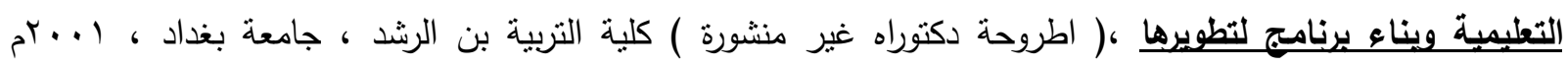

^- الخطيب ، أحدد و مرداح الخطيب. تدريب المعلمين على أساس الكفايات ، المهارة والأداء، الحلقة الثانية مجلة

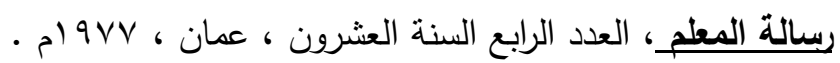

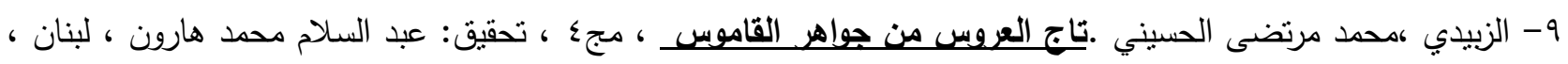

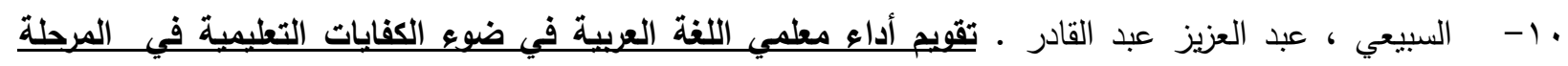

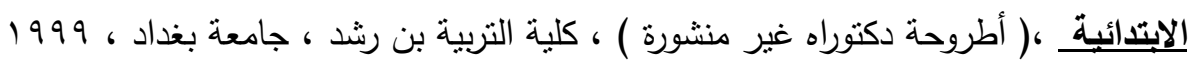

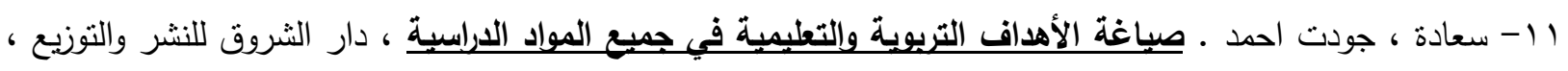

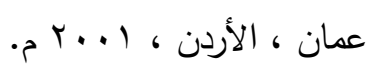
rا- السعدي ، عماد توفيق ـ أساليب تلدريس اللغة العربية ، طا ، دار الأمل للنشر والتززيع ، الأردن كو99 ام . 
با - الثمري ، ثامر نجم عبود ـ تقويم أداع معلمي اللغة العربية في تعليم مادة المحادثة في المرحلة الابتائية ( رسالة

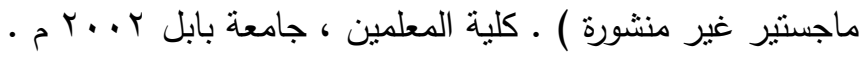

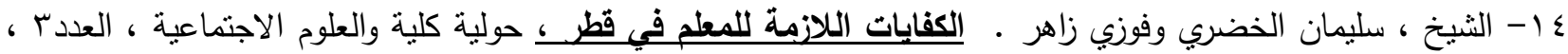
جامعة قطر المات

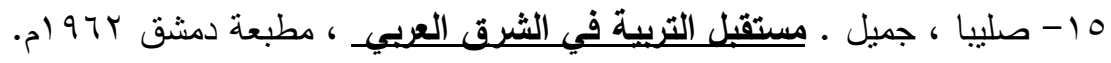

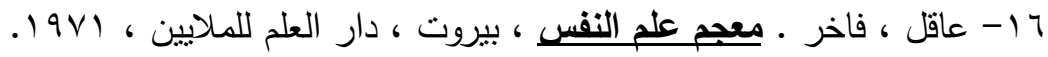
IV

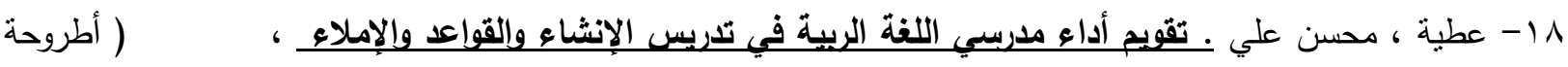

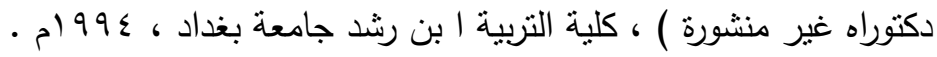

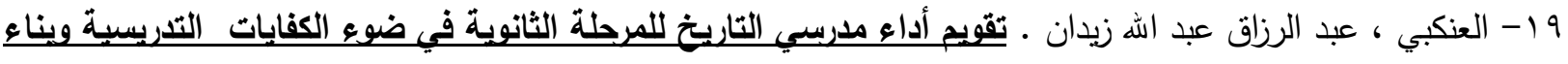

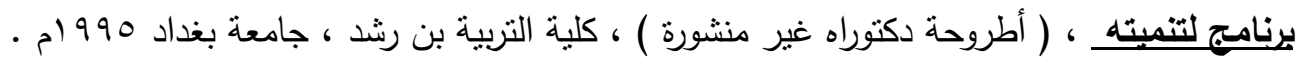

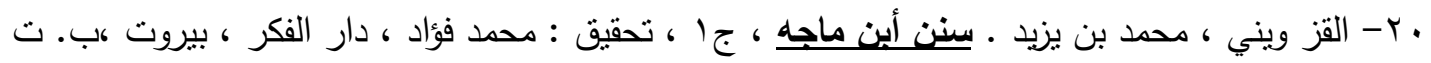

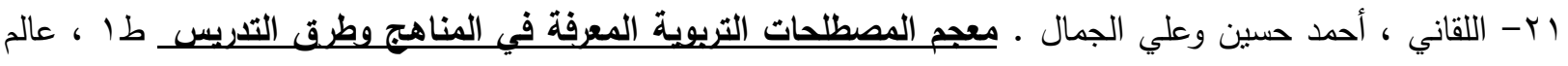
الكتب ، 1997 ام .

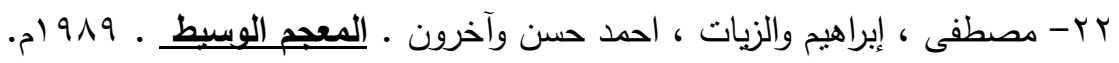

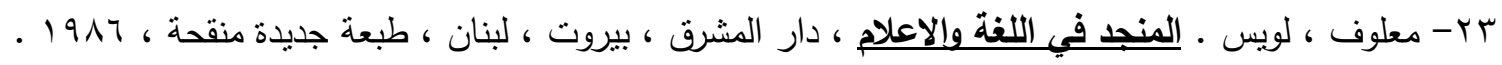

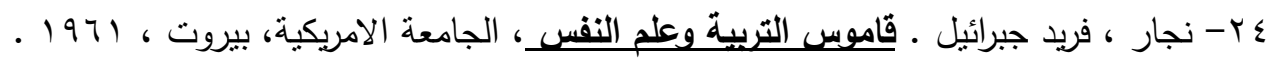

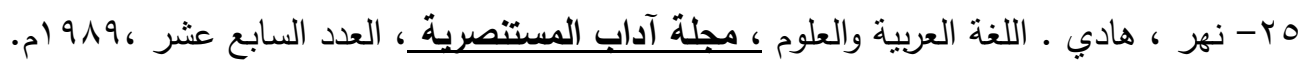

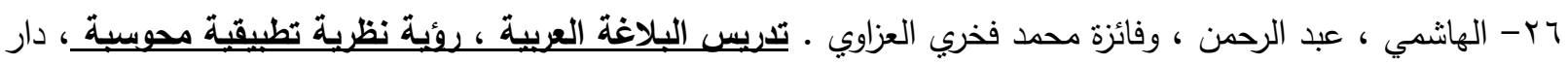

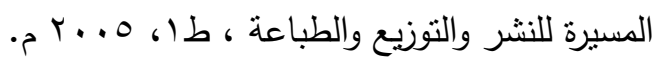
VY - هلا ، علي احمد • الكفايات التدريسية اللازمة لمعلمي اللغة العربية في ضوع التقويم البليل ويناء برنامج تدريبي

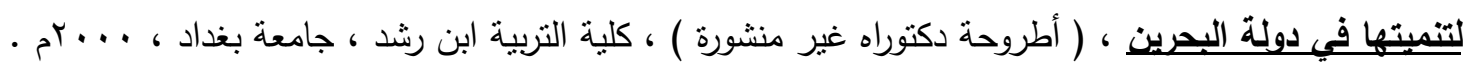

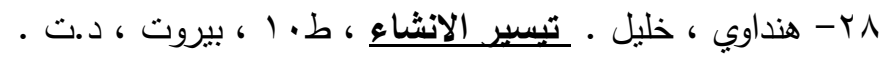




\section{الملحق (1)}

المهارات التعليمية التي ينبغي للمعلم أن يمتلكها في تدريس المحادثة

\begin{tabular}{|c|c|c|c|c|c|}
\hline 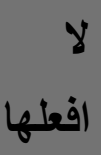 & أنادراً & افئماً & المهارات التعليمية & $ت$ & 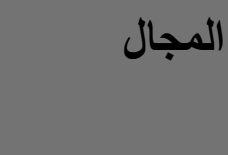 \\
\hline & & & اصوغ الأهداف الخاصة للدرس بصورة واضحة . & -1 & \multirow{8}{*}{ 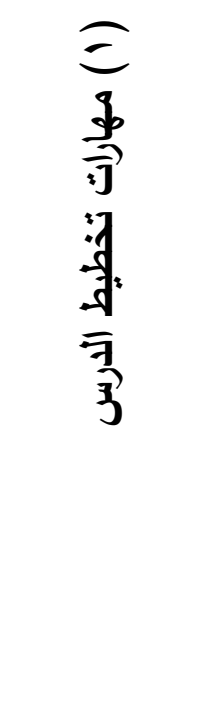 } \\
\hline & & & استععل الوسائل التعليمية المناسبة للدرس • & $-r$ & \\
\hline & & & ابين الثواهد التي استعطلها في الموضوع • & $-r$ & \\
\hline & & & اكتب توجيهات للتلاميذ حول كتابة الموضوع • & $-\varepsilon$ & \\
\hline & & & ابين الآلية التي يعرض بها الموضوع • & -0 & \\
\hline & & & الأعداد المسبق للحديث . & -7 & \\
\hline & & & اضع بداية للحديث ونهاية له ـ . & $-v$ & \\
\hline & & & اذكر الافكار الرئيسة للحديث . & $-\wedge$ & \\
\hline & & & بخط واضب الموضوع او الموضوعات المطروحة على السبورة & -1 & \multirow{6}{*}{ 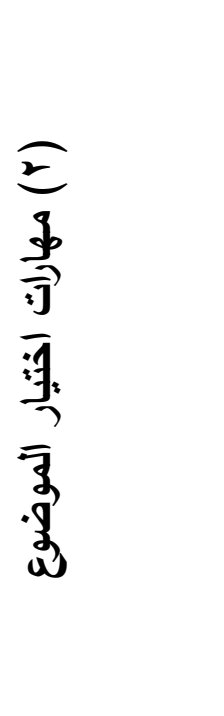 } \\
\hline & & & اربط الموضوع بييئة الطالب . & $-r$ & \\
\hline & & & اقدم موجزاً عن طبيعة الموضوع • & $-\mu$ & \\
\hline & & & الحديث للموضوع المختار بإيجاز مراعياً سلامة اللغة في & $-\varepsilon$ & \\
\hline & & & عما يجول في انفسهم • مواقف تعليمية تشجع التلاميذ على التحدث بحرية & -0 & \\
\hline & & & أركز على الفكرة المعينة . & -7 & \\
\hline
\end{tabular}




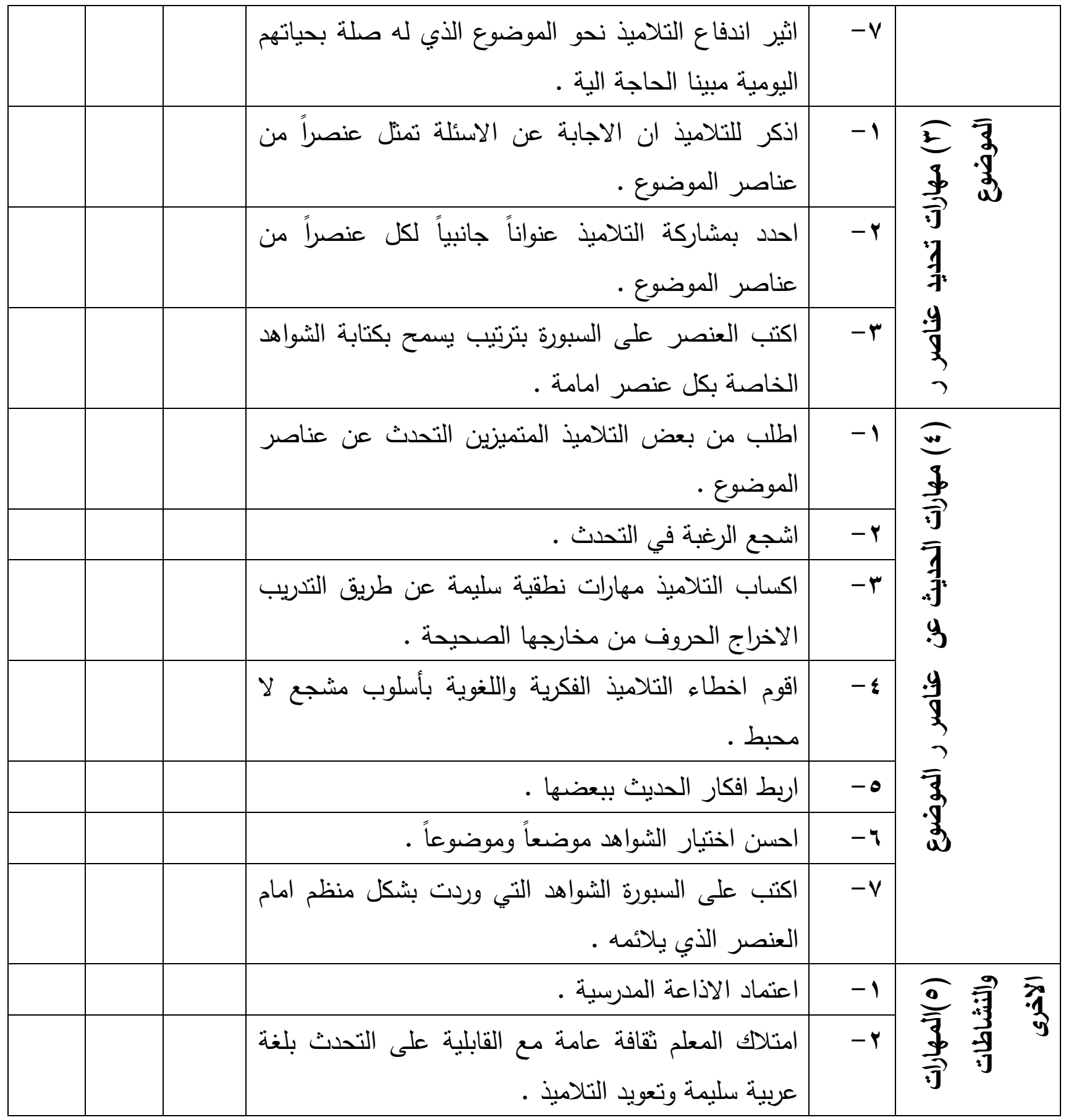




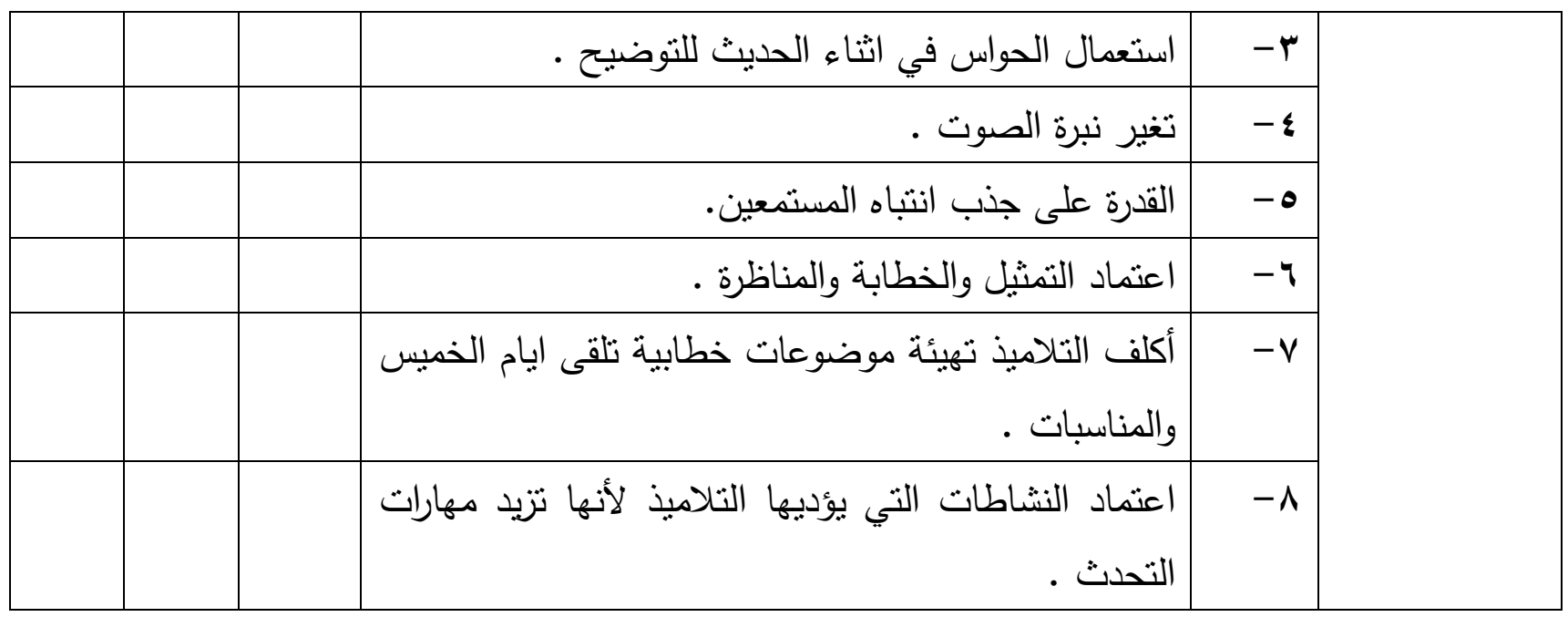




\section{ملحق (r)}

أسماء الخبراء والمحكمين الذين استعان بهم الباحث مرتبة بحسب الحروف الهجائية والقب العلمي

\begin{tabular}{|c|c|c|}
\hline التخصص & أسماء الخبراء & 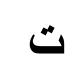 \\
\hline طرائق تدريس اللغة العربية & أ.د جمعة رشيد كضاض & 1 \\
\hline طرائق تدريس اللغة العربية & أ.د حسن علي فرحان العزاوي & r \\
\hline طرائق تدريس اللغة العربية & أ.د سعد علي زاير & r \\
\hline طرائق تدريس اللغة العربية & أ.م.د رحيم علي صالح & $\varepsilon$ \\
\hline طرائق تدريس اللغة العربية & أ.م.د رقية عبد الأئمة عبد اله العبيدي & 0 \\
\hline طرائق تدريس اللغة العربية & أ.م.د رهيف ناصر العيساوي & 7 \\
\hline طرائق تدريس اللغة العربية & أ.م.د ضياء عبد الله التميمي & $\checkmark$ \\
\hline طرائق تدريس اللغة العربية & أ.م.د علي محمد عبود العبيدي & $\wedge$ \\
\hline طرائق تدريس اللغة العربية & م.د أزهار حسين إبراهيم & 9 \\
\hline طرائق تدربس اللغة العربية & م.د تماضر حميد مهدي & 1 . \\
\hline
\end{tabular}

